\title{
Flow Transition Design in Hydraulic Structures
}




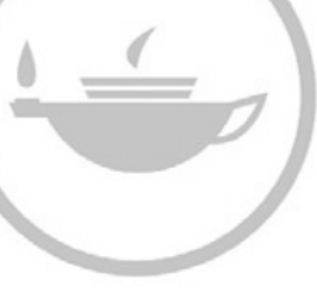

$$
\begin{aligned}
& \text { Taylor \& Francis } \\
& \text { Taylor \& Francis Group }
\end{aligned}
$$

http://taylorandfrancis.com 


\section{Flow Transition \\ Design in Hydraulic Structures}

S.K. Mazumder

CRC Press
Taylor \& Francis Group
Boca Raton London New York 
CRC Press

Taylor \& Francis Group

52 Vanderbilt Avenue,

New York, NY 10017

(C) 2020 by Taylor \& Francis Group, LLC

CRC Press is an imprint of Taylor \& Francis Group, an Informa business

No claim to original U.S. Government works

Printed on acid-free paper

International Standard Book Number-13: 978-0-367-23638-0 (Hardback)

This book contains information obtained from authentic and highly regarded sources. Reasonable efforts have been made to publish reliable data and information, but the author and publisher cannot assume responsibility for the validity of all materials or the consequences of their use. The authors and publishers have attempted to trace the copyright holders of all material reproduced in this publication and apologize to copyright holders if permission to publish in this form has not been obtained. If any copyright material has not been acknowledged please write and let us know so we may rectify in any future reprint.

Except as permitted under U.S. Copyright Law, no part of this book may be reprinted, reproduced, transmitted, or utilized in any form by any electronic, mechanical, or other means, now known or hereafter invented, including photocopying, microfilming, and recording, or in any information storage or retrieval system, without written permission from the publishers.

For permission to photocopy or use material electronically from this work, please access www. copyright.com (http://www.copyright.com/) or contact the Copyright Clearance Center, Inc. (CCC), 222 Rosewood Drive, Danvers, MA 01923, 978-750-8400. CCC is a not-for-profit organization that provides licenses and registration for a variety of users. For organizations that have been granted a photocopy license by the CCC, a separate system of payment has been arranged.

Trademark Notice: Product or corporate names may be trademarks or registered trademarks, and are used only for identification and explanation without intent to infringe.

\section{Visit the Taylor \& Francis Web site at http://www.taylorandfrancis.com}

and the CRC Press Web site at

http://www.crcpress.com 
This book is dedicated to my family:

Sumitra Mazumder-my wife

Jayati Mozumdar-my elder daughter

Sudip Mazumder-my younger son 


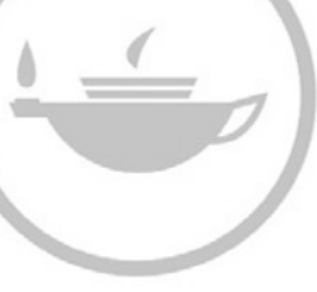

$$
\begin{aligned}
& \text { Taylor \& Francis } \\
& \text { Taylor \& Francis Group }
\end{aligned}
$$

http://taylorandfrancis.com 


\section{Contents}

Preface xiii

Author

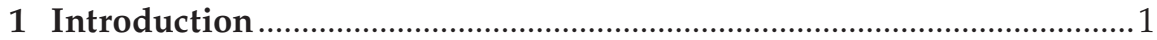

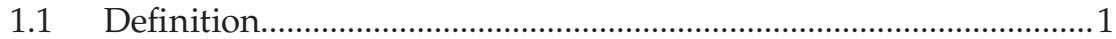

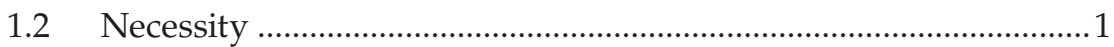

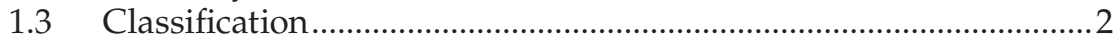

1.4 Contracting and Expanding Transitions and

Their Performance ....................................................................... 4

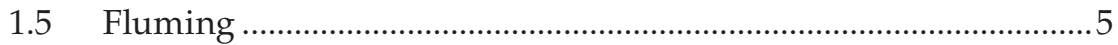

1.6 Length of Transition .........................................................................

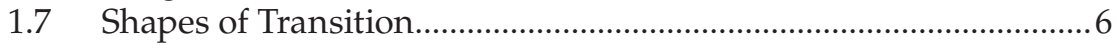

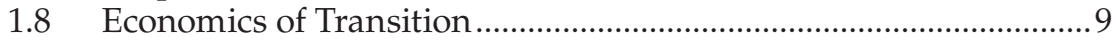

1.9 Historical Development of Transition.............................................. 11

1.9.1 Transition from One Subcritical to Another Subcritical Flow ....................................................................... 12

1.9.2 Transition from Subcritical to Supercritical Flow .............. 16

1.9.3 Transition from Supercritical to Subcritical Flow ..............20

1.9.4 Transition from Supercritical to Supercritical Flow.......... 21

1.9.5 Closed Conduit Pressure Flow Transition ..........................223

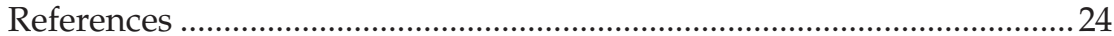

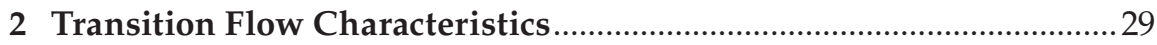

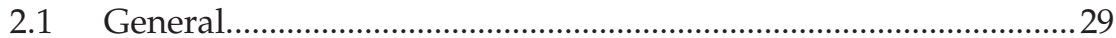

2.2 Flow Characteristics in Contracting and Expanding

Transitions with Free-Surface Subcritical Flow ..............................22

2.2.1 Head Losses in Transition ......................................................32

2.2.2 Hydraulic Efficiency of Contracting Transition ..................33

2.2.3 Hydraulic Efficiency of Expanding Transition with Eddy-Shaped Boundary …………………………….............36

2.2.4 Performance of Transition .....................................................38

2.2.5 Hydraulic Efficiency of Straight Expansion and

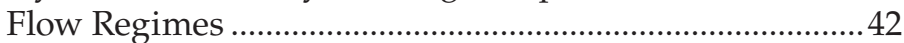

2.2.5.1 Concluding remarks with recommendation.......47

2.2.6 Optimum Length of Transition and Eddy Formation.......47

2.2.7 Stability of Flow in an Expansion......................................... 48

2.2.8 Specific Energy Principles ..................................................... 49

2.2.8.1 Application of Specific Energy Principles ...........52

2.2.9 Fluming of Free Surface Flow …………………………........52 
2.2.10 Choking of Subcritical Flow, Afflux, and Flow Profiles ...... 54

2.2.11 Fluming for Proportionality of Flow ……….......................57

2.3 Characteristics of Flow from a Subcritical to a Supercritical

State/Flow over Spillway .................................................................58

2.4 Characteristics of Flow from a Supercritical to a Subcritical

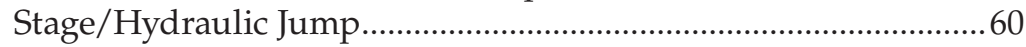

2.4.1 Hydraulic Jump Characteristics............................................. 61

2.4.1.1 Conjugate/Sequent Depth Relation........................61

2.4.1.2 Types of Jumps.......................................................6 62

2.4.1.3 Free and Forced Jumps ............................................63

2.4.1.4 Length of Jump ........................................................63

2.4.1.5 Height of Jump...............................................................

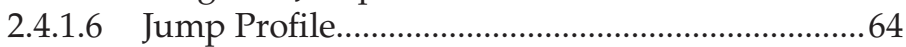

2.4.1.7 Energy Loss in Jump...............................................65

2.4.1.8 Efficiency of Jump ................................................65

2.4.1.9 Relative Loss of Energy …………………………...... 65

2.4.2 Velocity and Shear Stress Distributions in

Hydraulic Jump ..................................................................... 67

2.4.3 Boundary Layer Separation and Flow Regimes in

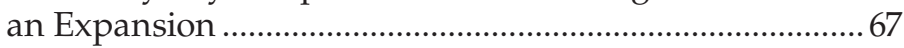

2.5 Supercritical Flow Transition ............................................................. 67

2.5.1 Flow Characteristics in Supercritical Flow Transition .....68

2.6 Flow Characteristics in Closed Conduit Flow Transitions ............69

2.6.1 Contracting Transition/Confuser.........................................70

2.6.2 Expanding Transition/Diffuser............................................71

2.6.2.1 Head Loss .................................................................. 71

2.6.2.2 Hydraulic Efficiency of Diffuser (E) ....................72

References .72

3 Different Methods of Hydraulic Design of Flow Transitions .............75

3.1 Introduction ...................................................................................

3.2 Design of Contracting Transition in Subcritical Flow .....................77

3.2.1 Assuming Linear Variation of Mean Velocity of Flow.....78

3.2.2 Assuming Variation of Mean Velocity as per Jaeger's

Equation ............................................................................... 80

3.2.3 Hinds's Method of Design ....................................................... 81

3.3 Design of Expanding Transition in Subcritical Flow .......................82 82

3.3.1 Assuming Linear Variation of Mean Velocity of Flow..... 82

3.3.2 Assuming Variation of Mean Velocity as per Jaeger's

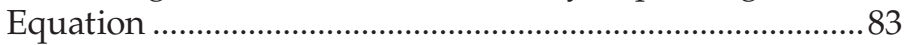

3.3.3 Hinds's Method of Design of Outlet Transition ..................84

3.3.4 Limitations of Conventional Design Method of

Expanding Transition............................................................... 85

3.4 Design of Transition from Subcritical to Supercritical Flow .........86

3.4.1 Ogee-Type Spillway/Creager's Profile ................................... 86 
3.4.2 Side Channel-Type Spillway ................................................... 88

3.4.3 Shaft-Type Spillway …………………………………….....91

3.4.3.1 Design of Crest Profile..............................................93

3.4.3.2 Design of Transition Profile .................................... 95

3.4.3.3 Determination of Conduit Size (d) of the Shaft .... 95

3.5 Design of Supercritical Flow Transition ............................................96

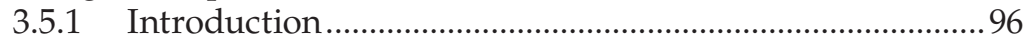

3.5.2 Mechanism of Shock Waves...............................................97

3.5.3 Design Criteria of Supercritical Transition ……………......97

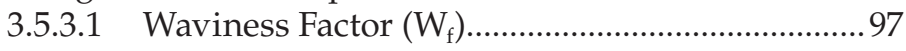

3.5.3.2 Coriolis Coefficient $(\alpha)$.........................................97

3.5.3.3 Lateral Momentum Transfer Coefficient $\left(\mathrm{T}_{\mathrm{f}}\right)$ ).....98

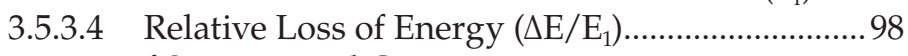

3.5.4 Design of Supercritical Contracting Transition..................98

3.5.5 Design of Expanding Supercritical Transition ................. 103

3.5.5.1 Design of Expansion with Rouse Reverse

Curve.................................................................... 107

3.6 Design of Transition in Closed Conduit under

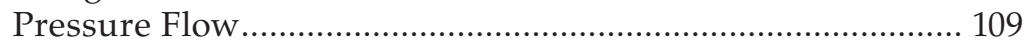

3.6.1 Design of Contraction .......................................................... 109

3.6.2 Design of Expansion........................................................... 109

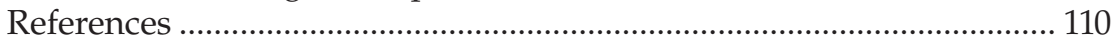

\section{Appurtenances for Economic and Efficient Design of Transition}

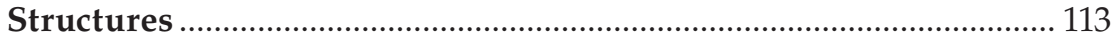

4.1 Introduction ................................................................................. 113

4.2 Classical Methods of Boundary Layer Flow Control in

Subcritical Flow Expansive Transition........................................... 116

4.2.1 Prandtl and Coworkers ..................................................... 116

4.2.2 Flow Characteristics in Wide-Angle Expansion................ 116

4.2.3 Use of Triangular Vanes to Control Boundary Layer Separation ......................................................................... 117

4.3 Performance of Subcritical Expansion with

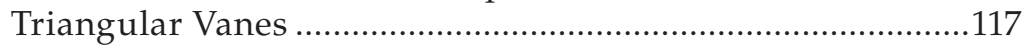

4.3.1 Hydraulic Efficiency of Expansion..................................... 118

4.3.2 Velocity Distribution at Exit of Expansion..........................120

4.3.3 Standard Deviation of Bed Shear Distribution and Scour .............................................................................. 120

4.3.4 Separation of Flow and Eddies ........................................... 121

4.3.5 Experimental Results .......................................................... 121

4.3.6 Optimum Geometry of Triangular Vanes for Best

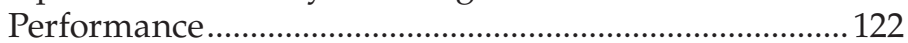

4.3.6.1 Optimum Submergence (for Vane Height)........122

4.3.6.2 Optimum Length $(\mathrm{L} / \mathrm{T})$, Spacing $\left(\mathrm{U} / \mathrm{B}_{1}\right)$, and Inclination $(\theta)$ of Triangular Vanes 


\subsubsection{Design Curves for Optimum Geometry of}

Vanes for Best Performance 125

4.4 Use of Bed Deflector for Control of Separation in

Subcritical Expansion.

4.5 Control of Separation with Adverse Slope to Floor of

Subcritical Expansion

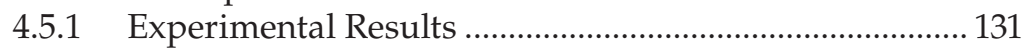

4.6 Transition from Supercritical to Subcritical Flow with

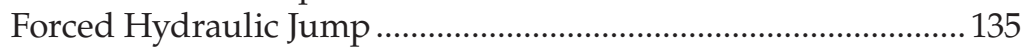

4.6.1 USBR-Type Stilling Basin ................................................. 135

4.6.2 Development of Stilling Basin with Diverging Side Walls

4.6.3 Stabilizing Rollers in Expansion with Adverse Slope to Basin Floor.

4.7 Control of Shock Waves in Supercritical Transition

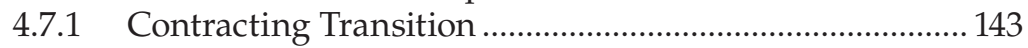

4.7.2 Expanding Transition......................................................... 143

4.7.3 Control of Shock Waves with Adverse Slope to Floor and Drop at Exit

4.8 Use of Appurtenances for Improving Performance of

Closed Conduit Diffuser/Expansion ............................................ 148

References

5 Illustrative Designs of Flow Transitions in Hydraulic Structures.

5.1 Introduction ........................................................................... 157

5.2 Design of Subcritical Transition for a Concrete Flume

Illustrating Hinds's Method of Design ........................................ 157

5.2.1 Inlet Transition ................................................................. 157

5.2.1.1 Determination of Length ................................ 157

5.2.1.2 Determination of Flow Profile Corrected for

Friction Loss....................................................... 160

5.2.1.3 Determination of Structural Dimensions and Plan of Transition ...................................... 162

5.2.2 Outlet Transition ............................................................... 162

5.3 Design of Subcritical Transition for an Aqueduct with

Warped-Type Hinds's Inlet Transition and Straight

Expansion with Adverse Bed Slope ............................................ 162

5.3.1 Inlet Contracting Transition ........................................... 162

5.3.1.1 Width of Aqueduct.......................................... 163

5.3.1.2 Length of Contracting Transition ...................... 163

5.3.1.3 Computation of Flow Profile ............................ 163

5.3.1.4 Hinds's Method of Design of Contracting

Transition.......................................................... 164

5.3.2 Design of Expanding Transition with Adverse Bed Slope....166

5.3.2.1 Length 
5.3.2.2 Bed Slope 166

5.4 Design of Subcritical Contracting Transition Assuming Linear Variation of Mean Velocity and Expanding

Transition Provided with Triangular Vanes ................................ 167

5.4.1 Contracting Transition ....................................................... 167

5.4.1.1 Width $\left(\mathrm{B}_{0}\right)$ at the End of Inlet Transition i.e. Width of Flume .................................................. 167

5.4.1.2 Flow Depth $\left(\mathrm{y}_{0}\right)$, Mean Velocity of Flow $\left(\mathrm{V}_{0}\right)$, and Froude's Number of Flow $\left(\mathrm{F}_{0}\right) \ldots \ldots \ldots \ldots \ldots \ldots \ldots . . . . .168$

5.4.1.3 Mean Width of Flow at Different Sections/ Plans and Profile of Water Surface .................... 168

5.4.2 Design of Straight Expanding Transition with Triangular Vanes. 169

5.4.2.1 Determination of Model Scale............................ 169

5.4.2.2 Determination of Model Flow $\left(\mathrm{Q}_{\mathrm{m}}\right)$ and Froude's Number $\left(\mathrm{F}_{0}\right)$........................................... 170

5.4.2.3 Determination of Vane Dimensions ................... 170

5.4.3 Design of an Elliptical Guide Bank for a Flumed

Bridge as per Lagasse et al. (1995) ....................................... 170

5.4.3.1 Waterway ……………………………………..... 170

5.4.3.2 Length of Guide Bank ........................................... 172

5.5 Design of a Canal Drop Illustrating the Design of (a) Inlet Subcritical Transition by Jaeger Method, (b) Subcritical to Supercritical Transition with Ogee-Type Profile, and

(c) Supercritical to Subcritical Transition in a Basin with

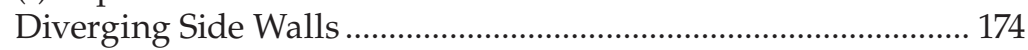

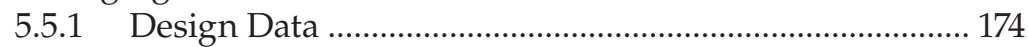

5.5.2 Computation of Flume Width at Throat $\left(\mathrm{B}_{0}\right)$ and Crest Height $(\Delta)$.

5.5.2.1 Design of Contracting Transition by Jaeger's Method .................................................................... 175

5.5.2.2 Design of Ogee-Type Glacis ................................. 175

5.5.2.3 Design of Stilling Basin with Diverging

Side Walls and Provided with Adverse Slope to Basin Floor.

5.6 Design a Stilling Basin of USBR Type III for an Ogee-Type Spillway

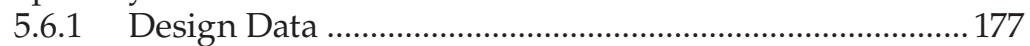

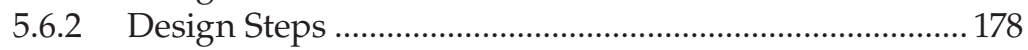

5.7 Design of Supercritical Transition ................................................ 180

5.7.1 Contracting Transition ...................................................... 180

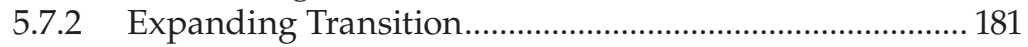

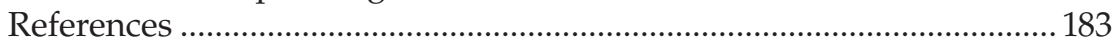




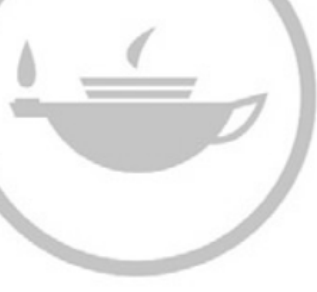

$$
\begin{aligned}
& \text { Taylor \& Francis } \\
& \text { Taylor \& Francis Group }
\end{aligned}
$$

http://taylorandfrancis.com 


\section{Preface}

As a young engineer in a river valley project, I had the opportunity for designing a number of canal-regulating and cross-drainage structures. Flow transitions had to be provided in all such structures for economy, and smooth flow through the structures had to be ensured. Cylindrical- and elliptical-type transitions were usually provided. Flow characteristics in plain eddy-shaped expansive transitions of different lengths were studied in subcritical flow as my dissertation topic at Indian Institute of Technology (IIT, Kharagpur). It was noticed that the flow always separated from the boundary resulting in poor hydraulic efficiency and nonuniform velocity distribution at the exit. Further investigations on subcritical flow transition were carried out in my PhD study under the late Professor J.V. Rao at IIT, Kharagpur, with the objective of improving the flow condition in a short straight expansion. Appurtenances such as triangular vanes and bed deflectors were used in controlling flow separation. At Delhi College of Engineering (now, Delhi Technology University), several appurtenances were developed through experimental investigations as part of research schemes sponsored by Council of Scientific and Industrial Research (CSIR), Department of Science and Technology (DST), All India Council of Technical Education (AICTE), etc. under Government of India. In February 1991, I was offered visiting professorship at Ecole Polytechnique Federal, Laussane (EPFL), Lausanne, Switzerland, where I had the opportunity to investigate supercritical flow expansion with Willi H. Hager who was at Versuchsanstalt fur Wasserbau (VAW), Ecole Technical Hoscichule, Zurich (ETHZ), Zurich, Switzerland.

Flow Transition Design in Hydraulic Structures covers all types of flow transitions: subcritical to subcritical, subcritical to supercritical, supercritical to subcritical with hydraulic jump, and supercritical to supercritical transitions. Classifications of transitions, various terms commonly used, review of past works, etc. are covered in the "Introduction" in Chapter 1. Chapter 2 deals with the characteristics of flow in different types of transitions. Procedures of hydraulic design of flow transitions in different structures are discussed in Chapter 3. Different types of appurtenances used to improve efficiency and control flow separation for uniform velocity distribution at exit of open-channel expansion and closed conduit diffusers are described in Chapter 4. Chapter 5 discusses the illustrative hydraulic design of flow transitions in some hydraulic structures.

I believe that experimental investigations with proper theoretical background offer a great scope in the hydraulic design of canal and river structures for economy and improved performance. 


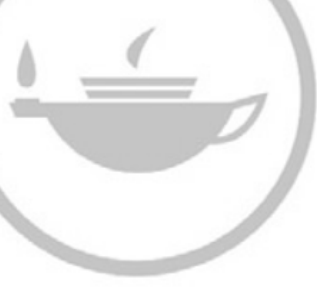

$$
\begin{aligned}
& \text { Taylor \& Francis } \\
& \text { Taylor \& Francis Group }
\end{aligned}
$$

http://taylorandfrancis.com 


\section{Author}

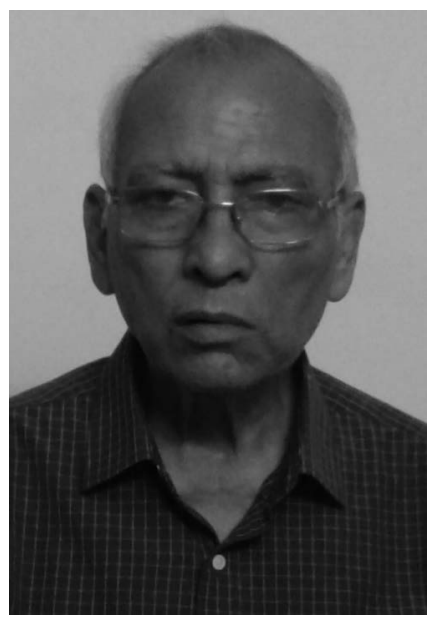

Professor S.K. Mazumder completed his PhD in Civil Engineering from IIT, Kharagpur. He is a Fellow of The Institution Of Engineers (India) IE(I), Indian Society for Hydraulics (ISH), Indian Water Resources Society (IWRS), and Central Board of Irrigation and Power (CBIP) and a member of International Association of Hydro-Environment Engineering and Research (IAHR), Indian Roads Congress (IRC), Institute of Public Health Engineers, India (IPHE), Indian Science Congress Association (ISCA), Consulting Engineer Association of India (CEAI), and Consultancy Development Center (CDC). He has 58 years of experience in teaching, research, and consultancy in hydraulics and water resources engineering. He was a principal investigator of several sponsored research schemes. He has guided 30 theses at postgraduate level and 10 projects at undergraduate level. He has published 192 technical papers in national and international journals and conferences, written one book on Irrigation Engineering (Tata McGraw-Hill Pub. Co., 1983) and contributed one chapter in two books published by Kluer Academic Publishers, London and Springer, Germany. He was the editorin-chief of the Proceedings of a National Conference on "Challenges in the Management of Water Resources and Environment in the Next Millennium: Need for Inter-Institute Collaboration" in 1999. He received several awards for his papers from IE(I) and IRC.

He was Dean of Technology Faculty, Delhi University, and AICTE (All India Council of Technical Education, Ecole Poltytechnic, Federal Laussane) Emeritus Fellow and visiting professor at EPFL, Switzerland. He received a lifetime achievement award from the Indian Society of Hydraulics (ISH) for his contribution in hydraulics and water resources engineering. 


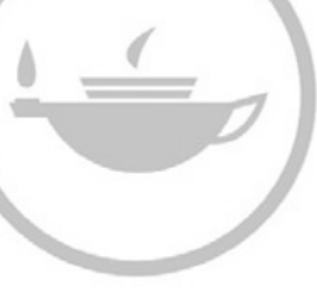

$$
\begin{aligned}
& \text { Taylor \& Francis } \\
& \text { Taylor \& Francis Group }
\end{aligned}
$$

http://taylorandfrancis.com 


\section{1}

\section{Introduction}

\subsection{Definition}

Transitions may be broadly defined as that portion of a nonuniform channel undergoing a change in the normal prismatic section. In open channel and closed conduit flows, there are situations when the normal section of flow is to be restricted. In falls, aqueducts, siphons, super-passages, bridges, and flumes, and in many other similar hydraulic structures, the original section of flow is often reduced in order to economize the construction cost. In another example, fluming of normal flow section offers an expedient device for measurement of discharge in e.g. Parshall $(1926,1950)$ flumes, critical flow meters (Mazumder \& Deb Roy, 1999), and Venturi meters (Mazumder, 1966a). All flow transitions bring about a change in depth and mean velocity of flow. To smoothly guide the flow from the normal wider section to the contracted narrow section (also called flumed section or simply flume), it is customary to provide a pair of transitions known as inlet or contracting transitions. Similarly, a pair of outlet or expanding transitions is provided to connect the flumed contracted section to the normal wider section to ensure smooth flow conditions. Figure 1.1 illustrates schematically the inlet and outlet transitions and flumed section in a weir with mean width (B) at entry, flumed width (b), depth of flow $\left(\mathrm{y}_{1}\right)$ at entry, critical depth $\left(\mathrm{y}_{\mathrm{c}}\right)$ at flumed section, upstream specific energy of flow $\left(\mathrm{E}_{\mathrm{f}}\right)$, downstream flow depth $\left(\mathrm{y}_{2}\right)$, downstream specific energy $\left(\mathrm{E}_{\mathrm{f} 2}\right)$, and different head losses $\left(\mathrm{H}_{\mathrm{L}}\right)$.

\subsection{Necessity}

Transitions are useful for reducing loss in head and to ensure that the flow in the flumed section is smooth without any undue disturbances in flow upstream and downstream of transitions. In unlined canals, if suitable transitions are not provided, the vortices created at the entry and exit of the flumed section create not only head losses but also lead to flow 


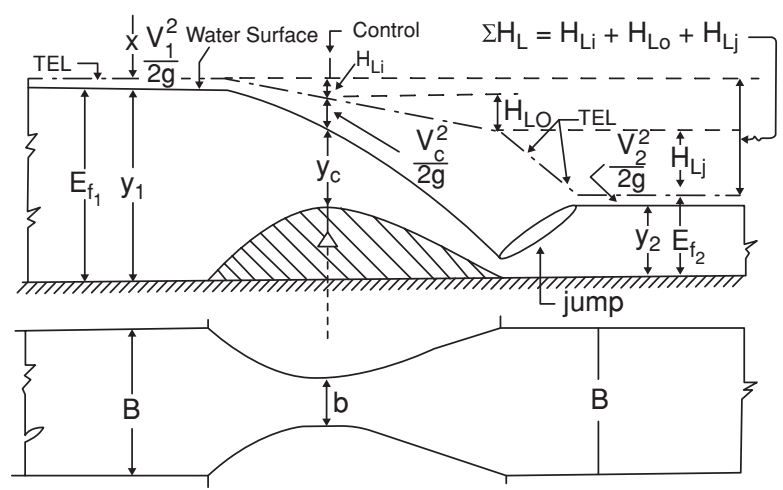

FIGURE 1.1

Inlet and outlet transitions and flumed section in a typical weir with hydraulic jump indicating head loss at entry $\left(\mathrm{H}_{\mathrm{Li}}\right)$, head loss at exit $\left(\mathrm{H}_{\mathrm{Lo}}\right)$, head loss in jump $\left(\mathrm{H}_{\mathrm{Lj}}\right)$, and total head loss $\left(\sum \mathrm{H}_{\mathrm{L}}\right)$.

nonuniformity resulting in nonuniform distribution of velocity and scouring, which requires costly protective measures. For example, when the normal waterway is restricted under a bridge (Mazumder et al., 2002) or in an aqueduct to economize the cost of construction of the bridge or the aqueduct, it is obligatory to provide suitable transitions at the entry and exit of the structure to reduce head losses and scour. The more the loss in head, the higher the afflux, which creates a lot of problems such as sediment deposition, nonuniformity of flow, and flow instability, thus requiring additional protective measures such as guide bunds, embankments, spurs, and pitching, which are expensive. Proper transitions ensure that the flow is normal within the flumed section, inside and outside the transitions. In an intake structure of hydropower plants, if suitable transitions are not designed, there will be a lot of problems such as vibration and cavitations, which will affect the performance of the power plant including its ultimate failure or reduction in life and high maintenance cost. In the desilting devices for hydroelectric plants, suitable transitions at entry and exit improve the performance of the structure ensuring greater efficiency and elimination of objectionable sediments causing damage to the water conductor system, turbines, and the diffusers.

\subsection{Classification}

Owing to the diversity of functions which hydraulic transitions are made to serve, a satisfactory scheme of classification is beset with many difficulties. In order to arrive at a general grouping of the various types of transitions, it is better to first discuss a few of their functions: 
i. Metering of flow e.g. in weirs, gates, venture-type flumes, and standing wave flumes

ii. Energy dissipation e.g. in drop structures

iii. Reduction of flow section e.g. in aqueducts and siphons

iv. Reduction of flow velocity to prevent scouring e.g. in flow diffusers

v. Increase of flow velocity to prevent shoaling e.g. in river training devices

vi. Minimization of head loss in order to reduce afflux e.g. in bridges and culverts

vii. Minimization of head loss e.g. in power canals and conduits so that the power plant has more output of energy.

Generally speaking, flumes may be divided into two main classes, which are described as follows:

Class I: Flumes with free water surface open to atmosphere with openchannel transitions.

Pressure on the surface is constant and more or less hydrostatically distributed varying along the depth with maximum pressure near bed.

Class II: Flumes with sealed water surface where roof is under pressure with closed conduit transitions such as confusers and diffusers.

Class I open-channel transitions can be further subdivided into the following three groups as per geometry of transition:

a. By changing width without changing bed level i.e. change in horizontal planes only. Venturi-type flumes, aqueduct transitions, etc. fall under this category.

b. By varying bed level without changing width i.e. change in vertical planes only as in case of weirs, spillways, etc.

c. By simultaneously varying both bed width and bed level i.e. change in both horizontal and vertical planes (Figure 1.1). Transitions in case of standing wave flumes, siphons, siphon aqueducts, etc. belong to this category.

Class I transitions may be further subdivided according to flow regimes in open channel, namely, subcritical and supercritical flow, as follows:

i. Transition from subcritical to another subcritical flow as in aqueduct and siphon

ii. Transition from subcritical to supercritical flow as in weirs and spillways 
iii. Transition from supercritical to subcritical flow with hydraulic jump as in energy-dissipating structures.

iv. Transition from supercritical to supercritical flow without any hydraulic jump as in chutes

Theoretically, it may be possible to convert one supercritical to another supercritical flow without any jump by providing a streamlined hump on the floor (Abdorreza et al., 2014). But such design is valid for one given flow only. As the flow changes, there is hydraulic jump due to boundary layer separation.

Class II transitions in closed conduits without any free surface are popularly used in pressure flow through pipes to reduce loss in head. For example, in orifice-type flow meters with abrupt contraction and expansion, the loss in head is extremely high. But in venture meters, well-designed inlet transition and provision of long diffuser appreciably reduce head loss and ensure a stable non-fluctuating flow through the pipe unlike an orifice meter in which a lot of fluctuations occur making the meter prone to more error due to error in measuring the differential head which is a function of flow. Similarly, a well-designed draft tube in a reaction-type turbine helps in increasing the net head on the turbine and improving its efficiency. Desilting chambers provided in head race tunnel (HRT) of hydropower plant will be ineffective unless they are well connected with the tunnel by providing efficient and well-designed transitions at the inlet and outlet of the desilting chamber operating under pressure.

Because of the fundamental differences between open-channel transitions with free water surface and closed conduit transitions operating under pressure, they will be dealt with separately.

Yet another classification of transition may be made on the basis of geometry of the channels and ducts:

i. Rectangular to rectangular

ii. Trapezoidal to rectangular and vice versa

iii. Circular to circular

iv. Rectangular and trapezoidal to circular and vice versa.

\subsection{Contracting and Expanding Transitions and Their Performance}

As mentioned earlier (Figure 1.1), in a contracting transition, the bed width of channel reduces, whereas in an expanding transition, the bed width increases in the direction of flow. Flow regimes in the contracting and 
expanding transitions depend on the regime of approaching flow and will be discussed in Chapter 2 .

Contracting and expanding transitions with free water surface are provided to perform one or more of the following functions:

a. To minimize loss in head within the transition. The more the loss in head, the more the afflux upstream. Too high afflux affects the regime condition of the channel and needs extra heightening of banks upstream. It causes submergence of areas lying upstream of the structure.

b. To prevent flow separation from boundaries so that there is no objectionable eddy generation within or outside the transition. Any defective contracting transition leads to poor performance of the expanding transition too following it. Objectionable scour and unstable flow may occur downstream if the transition design is improper.

c. To achieve normal and smooth flow conditions before, within, and after the flumed structure and to avoid undesirable eddies, cross waves, pressure fluctuations, and uniform flow conditions.

\subsection{Fluming}

When a canal or a road or a railway is to cross natural channel like rivers, it is often found economical to restrict the normal waterway of either the canal or the natural channel or both to economize the cost of construction. Flumes made up of concrete or other materials are used for transport of water over low-lying areas. The extent of restriction (Mazumder et al., 2002) of normal waterway of the canal and the river i.e. fluming is governed by several considerations such as economy, afflux and backwater reach, sediment deposition, flow stability, and cost of inlet and outlet transitions. The ratio between the flumed area of flow and the original normal flow section is called the fluming ratio. Further details about fluming and permissible fluming ratio are discussed in Chapter 2.

\subsection{Length of Transition}

As indicated in Figure 1.2, transition length is usually measured axially from the beginning to the end of the transition. Thus, the length of inlet or contracting transition is the axial length from the entry i.e. the point connecting 


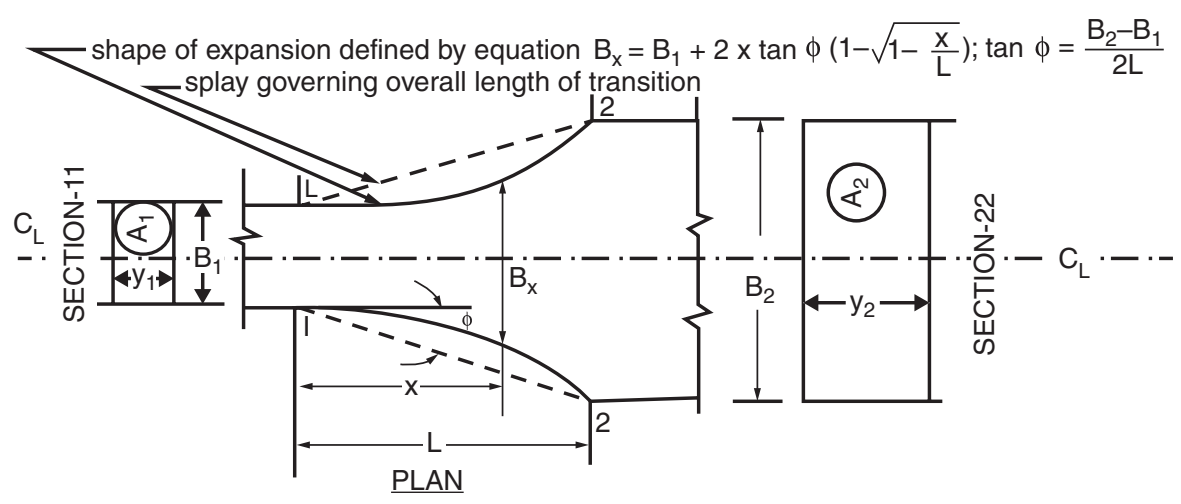

FIGURE 1.2

Transition shape and length (L) defined by an average sides play.

the normal channel with the transition to the point connecting the flume. Similarly, the length of the outlet or expanding transition is the axial length from the end of flume to the point where it ends connecting the normal channel section again. The axial length of transition is also sometimes defined by an average side splay defined by the slope of the line connecting the beginning and end of the transition as shown in Figure 1.2. Average side splay is given by the relation

$$
\text { Average splay }=L /\left[1 / 2\left(B_{2}-B_{1}\right)\right]
$$

where $\mathrm{L}$ is the axial length of transition, and $\mathrm{B}_{2}$ and $\mathrm{B}_{1}$ are the mean flow widths of the normal and flumed channels, respectively. For example, if the side splay for a transition is $3: 1$ with $B_{2}=30 \mathrm{~m}$ and $B_{1}=15 \mathrm{~m}$ (i.e. a fluming ratio $\left.B_{1} / B_{2}=0.5\right)$, the axial length of transition will be $22.5 \mathrm{~m}$.

\subsection{Shapes of Transition}

Transitions may be of different shapes: linear, circular, elliptical, parabolic, trochoidal, wedge shaped, warped shaped with reverse parabola, etc. Figure 1.3a and b illustrates a few transition shapes. Simplest transitions are linear with straight side walls. In a wedged-shaped transition, a trapezoidal channel is connected with the flumed rectangular section by a straight line. In case of warped-type transition as in case of Hinds's transition (Hinds, 1928), the side walls are curved and the water surface is assumed to be made of two reverse parabolic curves tangent to each other 
at the midpoint of length connecting the normal and flumed sections tangentially. It is difficult to construct Hinds's warped transition and it is costly too. However, Hinds's transition is hydraulically more efficient compared to a straight transition for the same length of transition.

(a)

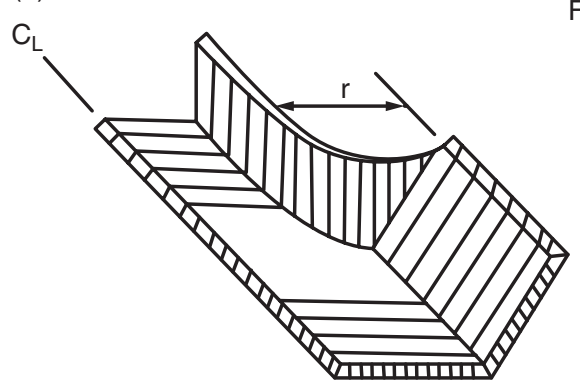

CYLINDRICAL QUADRANT

$\mathrm{C}_{\mathrm{L}}$

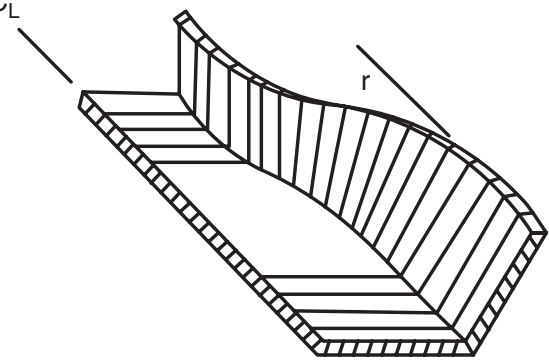

WARPED

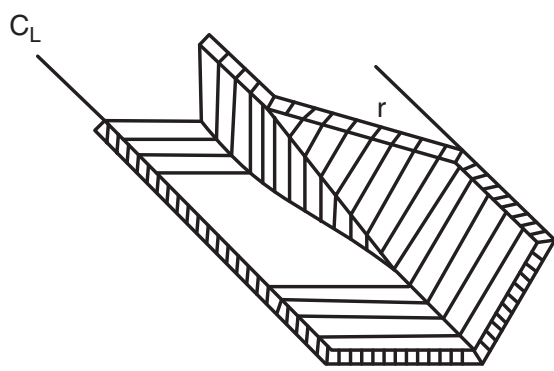

WEDGE

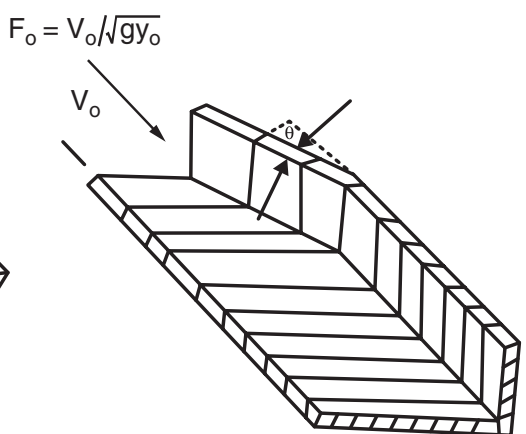

STRAIGHT LINE
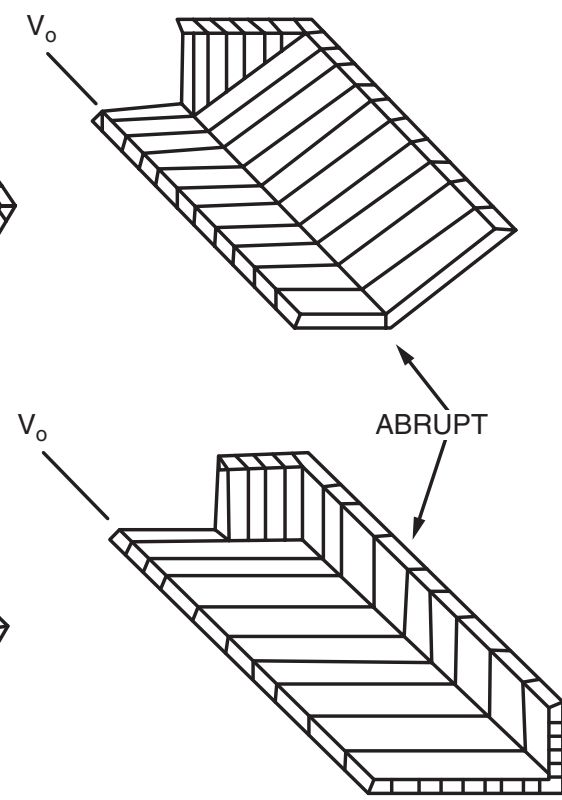

\section{FIGURE 1.3}

(a) Isometric views of some typical transitions in open-channel flow and (b) plan view of few contracting and expanding transitions: (i) cylindrical quadrant type, (ii) elliptical type, (iii) trochoidal-type transition, and (iv) warped-type inlet transition and sudden expansion followed by contraction at exit. 
(b)

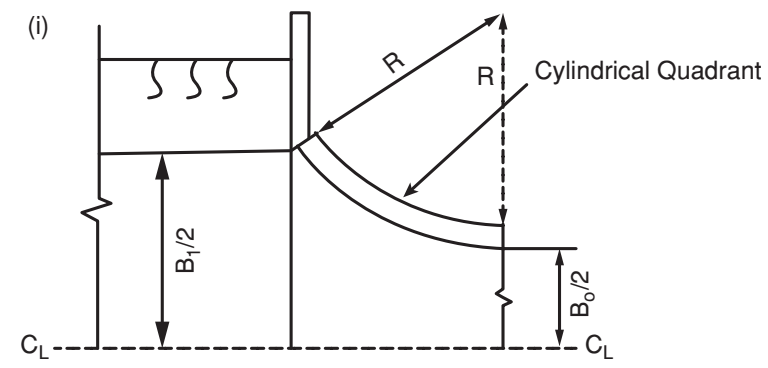

(ii)
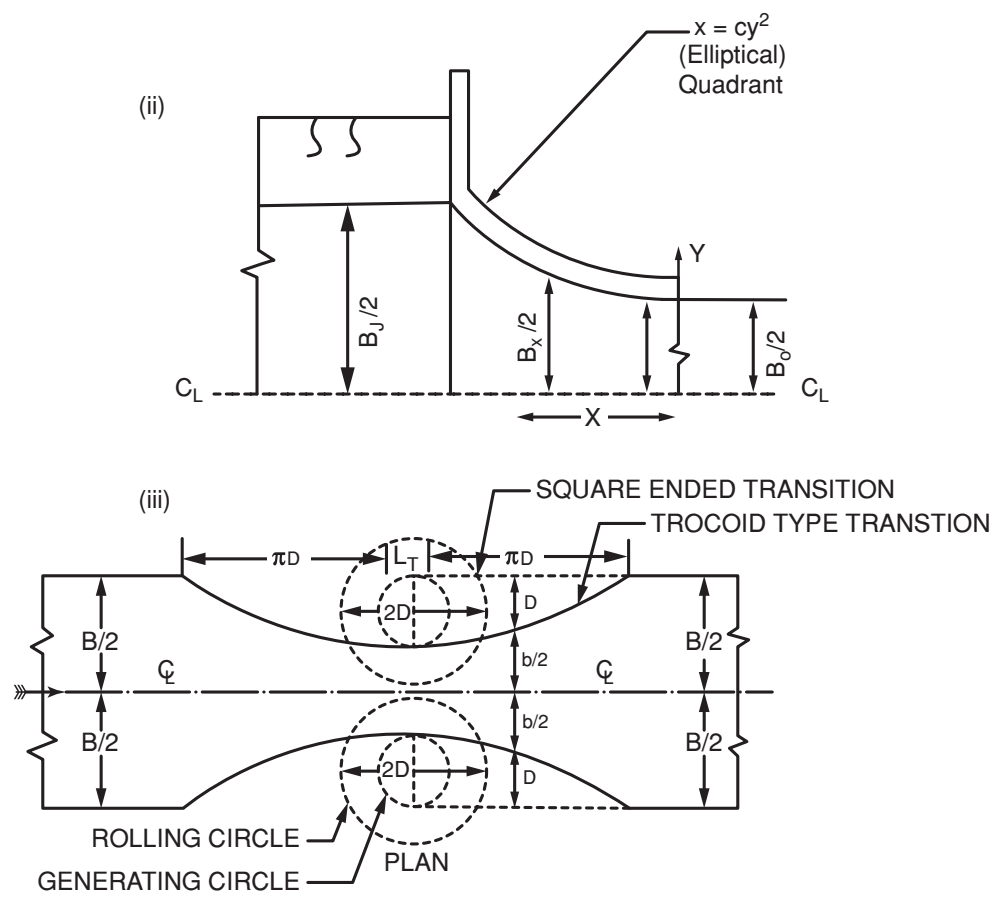

(iv)

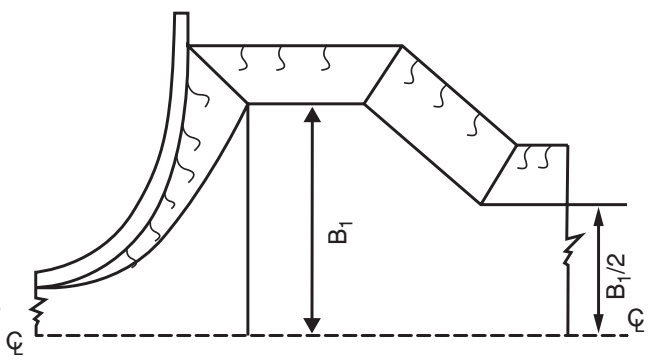

FIGURE 1.3 (CONTINUED)

(a) Isometric views of some typical transitions in open-channel flow and (b) plan view of few contracting and expanding transitions: (i) cylindrical quadrant type, (ii) elliptical type, (iii) trochoidal-type transition, and (iv) warped-type inlet transition and sudden expansion followed by contraction at exit. 


\subsection{Economics of Transition}

It may not be necessary to provide transitions where the fluming is very low i.e. fluming ratio $\left(B_{2} / B_{1}\right.$ in Figure 1.2$)$ is very high. Generally, transitions are required where the overall cost of the flumed structure and the transitions is minimum. An economic analysis should therefore be made to decide the extent of fluming to be made so that the total cost of the flumed structure and the transitions is the least. For example, when an aqueduct is to be constructed to carry the canal across a wide river, fluming of a trapezoidal earthen canal is absolutely necessary with the following objectives:

a. Reducing the cost of concrete flume

b. Connecting the earthen canal trapezoidal section with the concrete rectangular trough or a metallic/concrete pipe (depending on the flow magnitude) carrying the canal water above the river

In case the fluming is too high and proper transitions are not provided at the entry and exit ends of the flume, problems e.g. afflux, backwater, and siltation will occur upstream and scouring will take place on the downstream side. On the other hand, if the stream to be crossed is a minor one, it may be more economic to carry the canal in its normal earthen section and pass the stream underneath the canal by constructing an inverted siphon aqueduct. In such a situation, it is found more economical to flume the natural channel to minimize the cost of barrel conveying the stream flow. Depending upon the relative size of the canal and the stream as well as the relative elevations of their bed and water levels, different other types of cross-drainage arrangements are provided with transitions wherever necessary. If fluming of both the canal and the stream is found economical, four sets of transitions-two for the canal and two for the stream-will be needed.

Similarly, when a bridge is to be constructed over a river flowing in wide flood plains, it is customary to flume the river by providing guide bunds to reduce the bridge span for economy (Figure 1.4). Guide bunds are transition structures connecting the bridge opening with the normal river section. Excessive restriction (Mazumder et al., 2002) of flood plain width not only increases the cost of guide bund but also leads to several problems such as choking of flow resulting in very high afflux (Mazumder and Dhiman, 2003) upstream and hydraulic jump formation and scouring of river bed downstream. River may be unstable upstream due to siltation resulting in widening and outflanking of the bridge (Mazumder, 2010). In the absence of a suitably designed transition structure for proper diffusion of flow, high-velocity flow will scour away bed and banks of the river requiring costly foundation and protective works for the river as well as the approach embankments connecting the bridge with the road. Bradley (1970) performed a detailed investigation of relative economy of fluming a river 
(a)

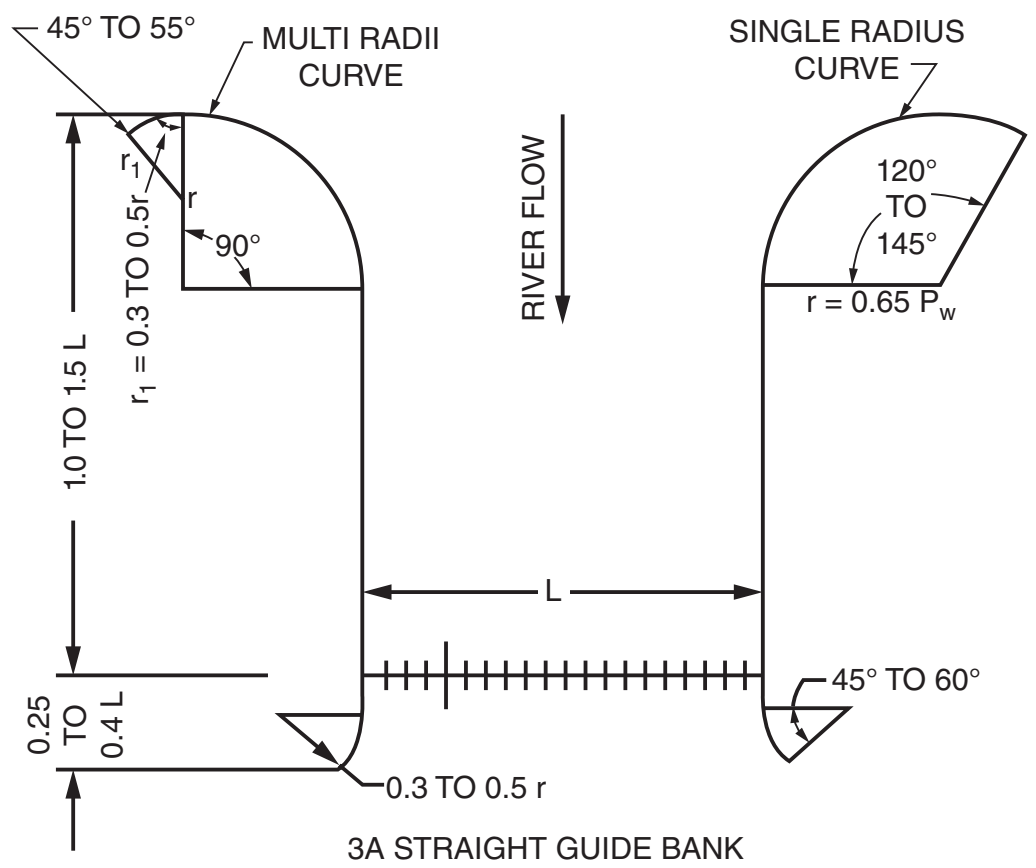

(b)

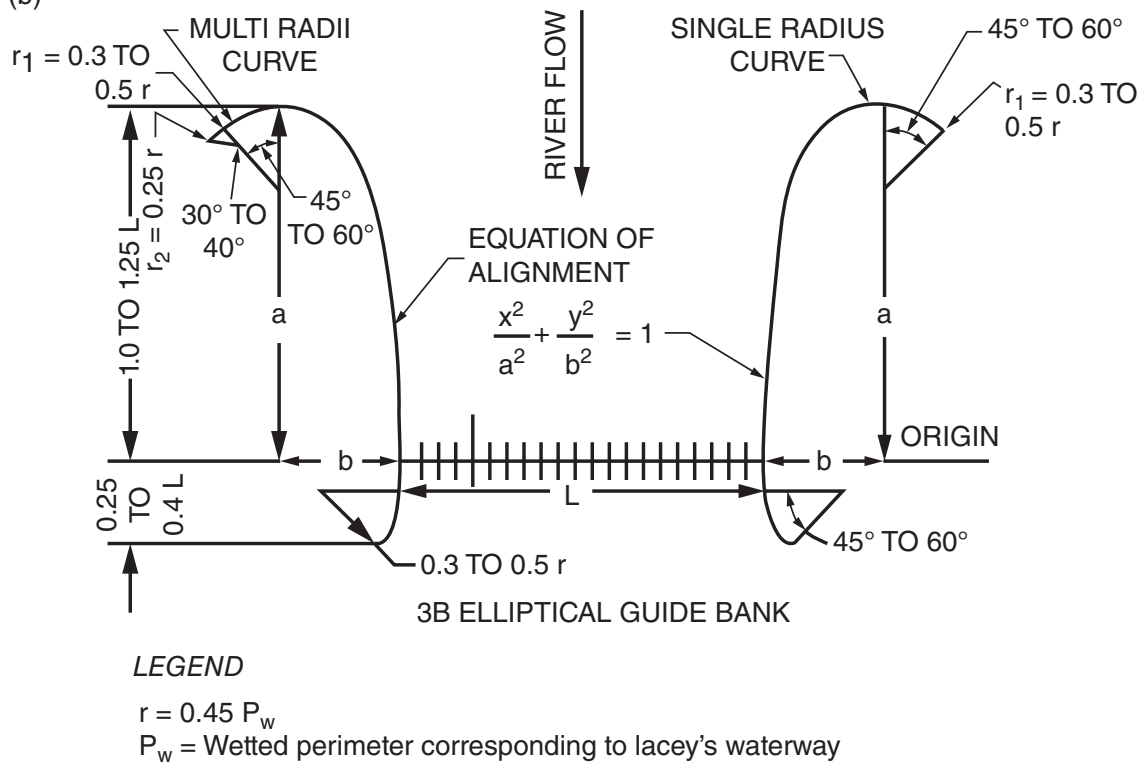

FIGURE 1.4

Different types of guide bunds used in bridges: (a) parallel type and (b) elliptical type. (Taken from IS-10751 by Bureau of Indian Standard, Government of India.) 


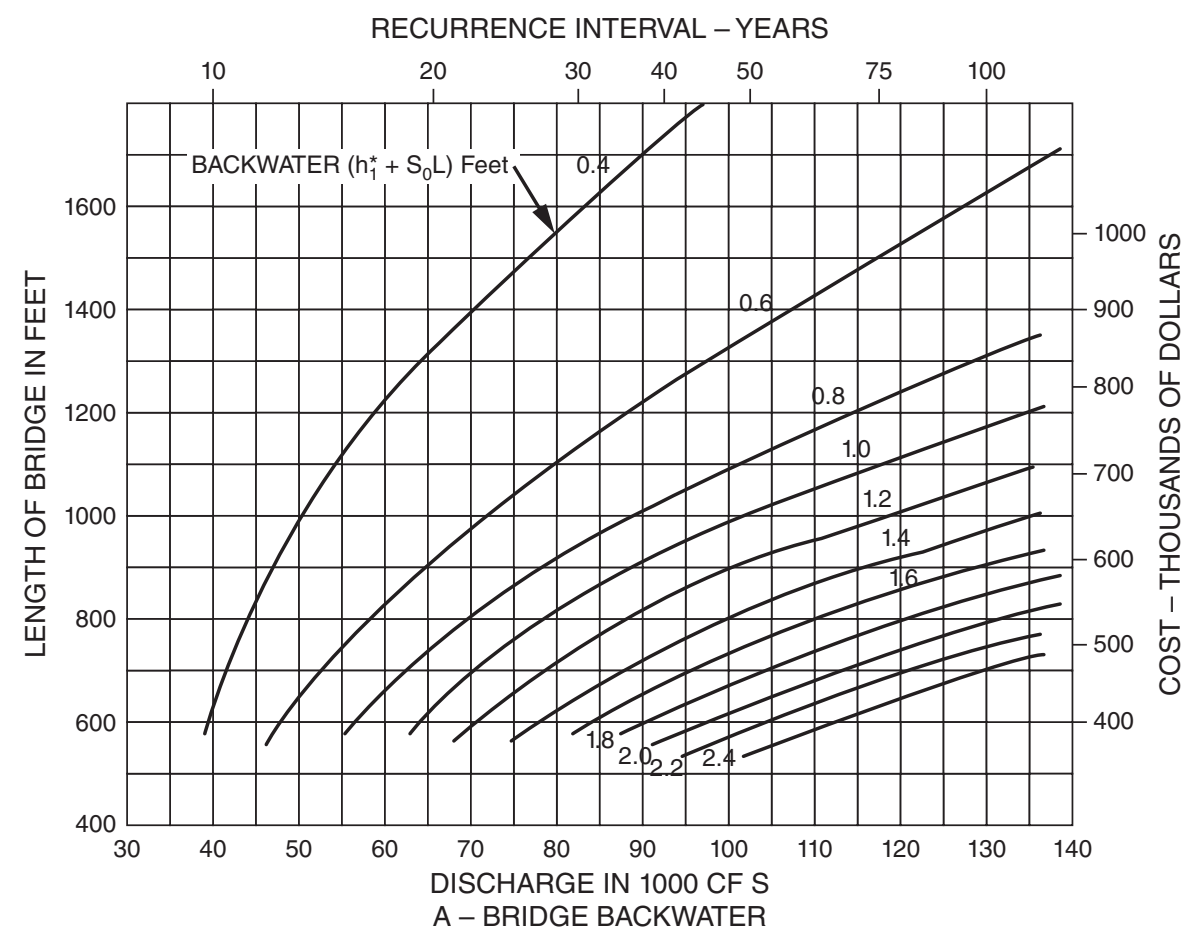

FIGURE 1.5

Relative economy of fluming of river under a bridge. (After Bradley, 1970.)

under the bridge (Figure 1.5). Further details of fluming of flood plains and guide banks are given in Chapters 2 and 5. Laggase et al. (1995) conducted an exhaustive study on guide bunds with elliptical-type transitions. An example has been worked out in Chapter 5 to illustrate the design of guide banks for a bridge on river Yamuna.

Similar to bridges, inlet and outlet transitions are commonly used in case of road culverts to reduce head loss and afflux, to improve the carrying capacity of culverts, and for diffusion of flow at exit of culverts so that scour and cost of protective works can be minimized.

\subsection{Historical Development of Transition}

Some of the different types and shapes of transitions which have been evolved over time are discussed briefly underneath. 


\subsubsection{Transition from One Subcritical to Another Subcritical Flow}

Warped-type transition proposed by Hinds (1928) for both inlet and outlet is very popular in both Europe and the United States for major hydraulic structures such as canal aqueducts and siphons. Hinds' transition is designed on the hypothesis that the water surface profile in the transition consists of two reverse parabolas which are tangential to each other at the mid length of transition and merge tangentially with the water surface at entry and exit. It also assumes a constant value of head loss coefficients along the transition length. Further details including design methodology for Hinds' transition are given in Chapters 3 and 5.

Mitra's (1940) hyperbolic transitions assuming linear variation in velocity and constant flow depth within the transition have been extensively used in India for the design of hydraulic structures. Width of the channel $\left(B_{x}\right)$ at any distance $x$ from the normal section is given by the relation

$$
\mathrm{B}_{\mathrm{x}}=\left(\mathrm{B}_{0} \mathrm{~B}_{1} \mathrm{~L}\right) /\left[\mathrm{B}_{0} \mathrm{~L}-\mathrm{x}\left(\mathrm{B}_{0}-\mathrm{B}_{1}\right)\right]
$$

where $\mathrm{B}_{0}$ and $\mathrm{B}_{1}$ are the mean widths of channel at the throat (or flumed section) and normal section, respectively, and $\mathrm{L}$ is the axial length of transition (Figure 1.2).

United States Bureau of Reclamation (USBR, 1952) developed a variety of transitions for open-channel subcritical flow. Different USBR transitions with corresponding head loss coefficients $\mathrm{C}_{\mathrm{i}}=\mathrm{H}_{\mathrm{Li}} /\left[\left(\mathrm{V}_{0}^{2}-\mathrm{V}_{1}^{2}\right) / 2 \mathrm{~g}\right]$ for inlet and $\mathrm{C}_{\mathrm{o}}=\mathrm{H}_{\mathrm{Lo}} /\left(\mathrm{V}_{0}^{2} / 2 \mathrm{~g}-\mathrm{V}_{2}^{2} / 2 \mathrm{~g}\right)$ for outlet, where $\mathrm{H}_{\mathrm{Li}}$ and $\mathrm{H}_{\mathrm{Lo}}$ are the head losses at inlet and outlet transitions, and $\mathrm{V}_{1}, \mathrm{~V}_{0}$, and $\mathrm{V}_{2}$ are the mean velocities of flow at entrance, flume, and outlet channels, respectively.

\begin{tabular}{lcc}
\hline Shape of Transition & $\mathbf{C}_{\mathbf{i}}$ & $\mathbf{C}_{\mathbf{~}}$ \\
\hline Square ended/abrupt & 0.30 & 0.75 \\
Straight line & 0.30 & 0.50 \\
Wedge type & 0.20 & 0.30 \\
Cylinder quadrant type & 0.15 & 0.25 \\
Warped type & 0.10 & 0.20 \\
\hline
\end{tabular}

USBR (1968) recommends simple shapes e.g. cylinder quadrant and straight line-type transition for unimportant structures where velocity is low. But in important hydraulic structures such as aqueducts and siphons, it recommends warped-shaped transition like Hinds transition.

Simons of United States Dept. of Interior (USDI), U.S. Bureau of Reclamation, developed monograms (no.33) for the design of canal transitions to minimize scour.

Kulandaiswami (1955) studied transitions-both contracting and expanding types - of conventional forms and determined head losses. He also made 
some tests with vanes and deflectors with the objective of controlling flow separation in expansions.

Jaeger (1956) used the following function for velocity variation along the transition

$$
\mathrm{V}_{\mathrm{x}}=\mathrm{V}_{1}+\mathrm{a}(1-\cos \Phi), \quad \text { where } \Phi=\pi \mathrm{x} / \mathrm{L}
$$

and derived the following expressions

$$
\mathrm{y}_{\mathrm{x}}=\mathrm{y}_{1}-\mathrm{a} / \mathrm{g}\left[\left(\mathrm{a}+\mathrm{V}_{1}\right)(1-\cos \Phi)-1 / 2 \operatorname{asin}^{2} \Phi\right]
$$

where

$$
\mathrm{a}=1 / 2\left(\mathrm{~V}_{0}-\mathrm{V}_{1}\right)
$$

and the continuity equation is given by

$$
\mathrm{V}_{\mathrm{x}} \mathrm{B}_{\mathrm{x}} \mathrm{y}_{\mathrm{x}}=\mathrm{Q}=\mathrm{V}_{1} \mathrm{~B}_{1} \mathrm{y}_{1}
$$

where $V_{x}, y_{x}$ and $B_{x}$ are the mean velocity, flow depth, and mean flow width, respectively, at any distance $x$ from the end of the throat/flumed section; $\mathrm{L}$ is the axial length of transition; and $\mathrm{V}_{0}$ is the mean flow velocity at the throat/flumed section. The width of flow section $\left(B_{x}\right)$ at any axial distance $x$ from the exit ends of transition can be found from the continuity equation (1.5). It can be shown that Jaeger's transition provides a smooth change in water surface, mean flow velocity, and mean width since $d y / d x$, $\mathrm{dv} / \mathrm{dx}$, and $\mathrm{db} / \mathrm{dx}$ are all equal to zero at the two ends of transition i.e. at $\mathrm{x}=0$ and $\mathrm{x}=\mathrm{L}$ resulting in a warped-type transition like Hinds transition. Design of an inlet transition for a canal drop by Jaeger's transition is illustrated in Chapter 5.

Central Board of Irrigation and Power (CBIP, 1957) Publication No. 6 "Fluming" deals with the design of flumes and transitions and recommends the following expression for finding the optimum divergence angle $(\alpha)$ of expansive transition:

$$
\tan \alpha=\left[\mathrm{C}(\mathrm{R} / \mathrm{B})^{\mathrm{n}}+0.018(\mathrm{R} / \mathrm{B})^{-1}\right] /\left\{\left(\mathrm{R}_{\mathrm{e}}^{1.5} \mathrm{e}\right) /\left(1-\mathrm{eF}_{\mathrm{r}}\right)+\mathrm{m}\left[2-\mathrm{r} /(\mathrm{r}-1)+\mathrm{eF}_{\mathrm{r}}\right]\right\}
$$

where $B$ is the channel width; $R$ is the hydraulic mean depth; $r$ is the expansion ratio; e is the kinetic energy correction factor; $\mathrm{m}$ is the momentum correction factor; $F_{r}$ and $R_{e}$ are Froude's number and Reynold's number of flow, respectively, in the downstream channel; and $C$ is a numerical constant. 
Chaturvedi (1963) developed a more general form of transition while investigating Mitra's (1940) hyperbolic transition. From his experimental study, he concluded that the following relation gives the best performance:

$$
x=\left[\left(L b^{1.5}\right) /\left(b^{1.5}-a^{1.5}\right)\right]\left[1-(a / y)^{1.5}\right]
$$

where $y$ is the half width of expansion at an axial distance $x$ from the normal section, $2 \mathrm{a}$ and $2 \mathrm{~b}$ are the mean widths at the throat and normal section, respectively.

Smith and $\mathrm{Yu}(1966)$ used baffles of rectangular section in expanding transition for preventing flow separation and achieving uniform velocity distribution after expansion. However, there is a lot of head loss in this arrangement.

Mazumder (1966b, 1967) tested expansive transitions of different lengths with shape representing the inner surface of the eddy generated in a sudden expansion. Ishbash and Lebedev (1961) measured such a boundary and developed the following expression for the boundary:

$$
\mathrm{B}_{\mathrm{x}}=\mathrm{B}_{0}+2 \mathrm{x} \tan \theta[1-(1-\mathrm{x} / \mathrm{L})]^{0.5}
$$

where $B_{x}$ is the width of channel at any distance $x$ measured from the end of flumed/throat section, $B_{0}$ is the width of throat/flumed section, and $\theta$ is the angle of divergence given by the relation

$$
\tan \theta=\left(\mathrm{B}_{1}-\mathrm{B}_{0}\right) / 2 \mathrm{~L}
$$

He measured head losses, axial velocity distributions, and separation patterns within and outside the transition to determine the optimum length of expansive transition. Efficiency $\left(\eta_{0}\right)$ of the transition, outlet head loss coefficient $\left(C_{o}=1-\eta_{\mathrm{o}}\right)$, and Coriolis coefficient at the exit end of the transition $\left(\alpha_{2}\right)$ were computed. Flow separation and nonuniform velocity distribution were observed in all cases even when the average side splay was as high as 10:1, resulting in low efficiency and high $\alpha_{2}$ value. Optimum splay of expansive transition corresponding to minimum head loss and minimum $\alpha_{2}$ value was found to vary between 7:1 and 9:1 depending on the shape of curves, discharge, and Froude's number of flow $\left(\mathrm{F}_{\mathrm{ro}}\right)$ at the throat. It was concluded that a straight expansion is better than a curved one when the average splay is higher than about 5:1. For shorter lengths with average sides play varying from 2:1 to 5:1, the curved expansion with tangential entry performs better than the straight one.

Rao (1951), Mazumder (1971), and Mazumder and Rao (1971) used a pair of short triangular vanes and bed deflectors for control of boundary layer separation and developed short expansion with straight side wall diverging at a side splay of 3:1. Without appurtenances, flow was found to separate right from the entry with a large and violent eddy on one side or the other resulting in extremely poor performance. On introduction of the appurtenances, there 
was no separation and the performance of expansion improved remarkably. As regards, inlet transition, a curved transition of either Jaeger type or even a circular curve ending tangentially at the throat/flumed section having an average side splay of 2:1, was found to be quite efficient.

Further details about the performance and design of subcritical transition by Mazumder (1969) are given in Chapters 2, 3, and 5.

Ramamurthy et al. (1970) adopted a local hump on the floor in an expansive transition to control the separation of flow.

Ahuja (1976) used Jaeger-type transition and conducted a model study on inlet transition with different axial lengths governed by average side splays varying from 0:1 (abrupt contraction) to 6:1 (six times the offset i.e. $6\left[1 / 2\left(B_{1}-B_{0}\right)\right]$. The maximum hydraulic efficiency $\left(\eta_{\max }=94 \%\right)$ was found to occur at an optimum average side splay of about 3.3:1. The corresponding minimum inlet head loss coefficient was found to be $C_{i(\min )}=0.064$ according to the following relation:

$$
\mathrm{C}_{\mathrm{i}}=\mathrm{H}_{\mathrm{Li}} /\left[1 / 2 \mathrm{~g}\left(\mathrm{~V}_{0}^{2}-\mathrm{V}_{1}^{2}\right)\right]=\left[\left(1 / \eta_{\mathrm{i}}\right)-1\right]
$$

where $V_{0}$ and $V_{1}$ are the mean velocities of flow at the throat/flumed and original channel sections, respectively, and $\mathrm{H}_{\mathrm{Li}}$ is the head loss in inlet transition. In fact, the drop in hydraulic efficiency of inlet transition $\left(\eta_{i}=90 \%\right)$ is marginal at 2:1 side splay. Efficiency $\left(\eta_{\mathrm{i}}\right)$ was found to decrease when the length of transition was more than the optimum length at 3.3:1 side splay.

Incidentally, Hinds (1928) recommends an angle of $12^{\circ} 30^{\prime}$, which corresponds to an average splay of about 5:1.

Vittal and Cheeranjeevi (1983) found the following equation for finding the mean width of an expanding transition representing the separating streamline of an eddy developed in a sudden expansion:

$$
\mathrm{B}_{\mathrm{x}}=\mathrm{B}_{0}+\left(\mathrm{B}_{2}-\mathrm{B}_{0}\right) \xi\left[1-(1-\xi)^{0.8-0.26 \sqrt{\mathrm{m}}}\right]
$$

where $\xi=x / L$; $m$ is the side slope of the wall in the transition zone; and $B_{x}$, $\mathrm{B}_{2}, \mathrm{~B}_{0}$, and $\mathrm{L}$ are as defined before.

Nasta and Garde (1988) developed the following expression for expansive transition based on the minimization of the head loss consisting of form loss due to separation and frictional head loss:

$$
\mathrm{B}_{\mathrm{x}}=\mathrm{B}_{0}+\left(\mathrm{B}_{2}-\mathrm{B}_{0}\right) \xi\left[1-(1-\xi)^{0.55}\right]
$$

Swamee and Basak (1991) studied expansive transitions of different shapes and developed the following expressions for a rectangular channel for minimum head loss:

$$
\mathrm{B}_{\mathrm{x}}=\mathrm{B}_{0}+\left(\mathrm{B}_{2}-\mathrm{B}_{0}\right)[2.52(\mathrm{~L} / \mathrm{x}-1) 1.35+1]^{-0.775}
$$


Swamee and Basak (1991) also developed an expansive transition for connecting a rectangular flumed section with a trapezoidal section by developing a large number of mathematical expressions for minimizing the separation and head loss in the transition.

\subsubsection{Transition from Subcritical to Supercritical Flow}

Transition from subcritical to supercritical flow takes place when the incoming subcritical flow gets choked. For example, when a dam or a weir (Ackers et al., 1978) of sufficient height is constructed in a channel such as a canal or a river, the flow upstream is subcritical. At the dam/weir crest where the specific energy is minimum, the flow is critical. Flow becomes supercritical downstream of the crest or control section as illustrated in Figures 1.1 and 1.6. Similarly, when a channel is contracted/flumed, to such an extent that the flow gets choked, the flow at the throat becomes critical and downstream of the constricted/flumed section, the flow becomes supercritical. Such phenomena occur in a venture-type (Parshall, 1950) or critical flowmeter (Chow, 1973) used for flow measurement in open channels (Bos, 1975). There is a unique head-discharge relation when the flow is in a critical state at the control section. In standing wave-type flumes (IS:6062, 1986; Deb Roy, 1995; Mazumder \& Deb Roy, 1999), flow choking is achieved by simultaneous contraction of flow in both horizontal and vertical planes by fluming laterally and raising bed simultaneously. Further details about the development of flow choking by fluming laterally or raising the bed or by both will be discussed in Chapter 2. An example is worked out to illustrate the design of a proportional flow meter in Chapter 5.

Suitable transitions are needed for spillways in dams and weirs to prevent the separation of flow and cavitation damage. Historical development of such transitions is discussed in detail by Chow (1973) and USBR (1968).

Early crest profiles in dam spillways were based on a simple parabola designed to fit the trajectory of the lower nappe of a jet falling freely from a sharp crested notch. The general nondimensional equation to such a nappe profile can be expressed as

$$
\mathrm{y} / \mathrm{H}=\mathrm{A}(\mathrm{x} / \mathrm{H})^{2}+\mathrm{B}(\mathrm{x} / \mathrm{H})+\mathrm{C}+\mathrm{D}
$$

where $\mathrm{x}$ and $\mathrm{y}$ are the coordinates of the profile and $\mathrm{H}$ is the head (including head due to velocity $\left(\mathrm{v}_{\mathrm{a}}\right)$ of approach, $\left.\mathrm{h}_{\mathrm{v}}=\mathrm{v}_{\mathrm{a}}^{2} / 2 \mathrm{~g}\right)$. Based on the data of USBR (1968) collected from numerous tests performed by Hinds et al. (1945), Creager and Justin (1950), Ippen (1950), and Blaisdel (1954), the following nondimensional expressions give the values of the constants A, B, C, and D:

$$
A=-0.425+0.25\left(h_{v} / H\right)
$$




$$
\begin{gathered}
\mathrm{B}=0.411-1.603 \mathrm{~h}_{\mathrm{v}} / \mathrm{H}-\left[1.568\left(\mathrm{~h}_{\mathrm{v}} / \mathrm{H}\right)^{2}-0.892\left(\mathrm{~h}_{\mathrm{v}} / \mathrm{H}\right)+0.127\right]^{0.5} \\
\mathrm{C}=0.150-0.45\left(\mathrm{~h}_{\mathrm{v}} / \mathrm{H}\right) \\
\mathrm{D}=0.57-0.02(10 \mathrm{~m})^{2} \mathrm{e}^{10 \mathrm{~m}}
\end{gathered}
$$

where $\mathrm{m}=\mathrm{h}_{\mathrm{v}} / \mathrm{H}-0.208, \mathrm{~h}_{\mathrm{v}}=\mathrm{v}_{\mathrm{a}}^{2} / 2 \mathrm{~g}$, and $\mathrm{v}_{\mathrm{a}}$ is the velocity of approaching flow, which can be found from the relation

$$
\mathrm{v}_{\mathrm{a}}=\mathrm{q} /\left(\mathrm{P}+\mathrm{y}_{\mathrm{a}}\right)
$$

where $\mathrm{q}$ is the discharge per unit length of the dam/weir, $\mathrm{P}$ is the height of weir, and $y_{a}$ is the depth of water surface above the crest of the weir/ dam. It may be noted that the velocity of approach governs the trajectory profile. USBR (1968) gives the coordinates as a function of velocity approach head. USBR curves can be used for finding $x$ and y coordinates. An example to determine the transition profile (popularly called Creager's profile) has been worked in Chapter 5. In a very high dam, the velocity of approach is almost zero, and hence,

$$
\mathrm{A}=-0.425, \mathrm{~B}=0.055, \mathrm{C}=0.150 \& \mathrm{D}=0.559 \text {. }
$$

On the basis of USBR data, U.S. Army Corps of Engineers developed several standard shapes of the supercritical transition profile at its Waterways Experiment Station (WES) designated as WES standard spillway shapes which may be expressed as

$$
\mathrm{y} / \mathrm{H}_{\mathrm{d}}=-\mathrm{K}\left(\mathrm{x} / \mathrm{H}_{\mathrm{d}}\right)^{\mathrm{n}}
$$

where $H_{d}$ is the design head i.e. $\left(E_{1}-\Delta\right)$ (Figure 1.6) for finding the spillway profile, $\mathrm{k}$ and $\mathrm{n}$ values are the functions of velocity of approach head and slope of the upstream face, which are given by USBR from the experimental data (Chapter 2). It may be mentioned that the design head $\left(\mathrm{H}_{\mathrm{d}}\right)$ for the spillway profile is usually taken as the maximum head $(\mathrm{H})$ on the spillway corresponding to design discharge, since at discharges lower than the design discharge, the head above the spillway crest $(\mathrm{H})$ will be less than the maximum head, and as such the spillway face will be subjected to positive pressure. In case the design head $\left(\mathrm{H}_{\mathrm{d}}\right)$ is less than the maximum head, the spillway face will be subjected to negative pressure at head higher than design head which is likely to cause cavitation. But the coefficient of discharge $\left(\mathrm{C}_{\mathrm{d}}=\mathrm{Q} / \mathrm{LH}^{1.5}\right)$ will increase resulting in less head required to pass a given flood above the spillway and hence less submergence of catchment area. Here, L is the length of spillway (m), H is the head (m), and Q is the discharge over spillway $\left(\mathrm{m}^{3} / \mathrm{sec}\right)$. 


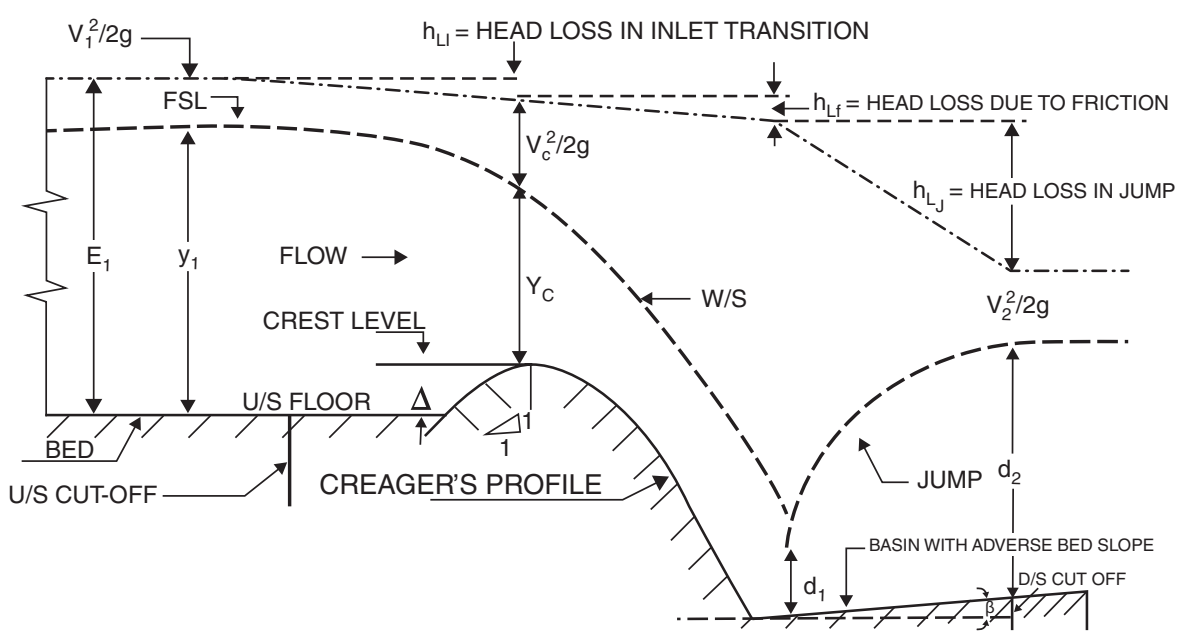

FIGURE 1.6

Flow over a spillway showing subcritical, critical, and supercritical flows and jump.

Upstream face of the spillway usually consists of compound circular curves made of radii $R_{1}$ and $R_{2}$ up to a point $X_{c}, Y_{c}$. After the point $X_{c^{\prime}}, Y_{c^{\prime}}$ the spillway face is normally kept straight as the subcritical flow velocity is very low and the pressure distribution is hydrostatic. The values of $X_{c^{\prime}} Y_{c^{\prime}} R_{1}$, and $R_{2}$ are given by USBR in Chapter 2. In case of low height of weir crest and low height of drops in water surface, as in canal drops, it is usual to provide straight glacis as transition-both upstream and downstream of the crestas illustrated in Figure 1.7.

However, where gates are provided above crest (nowadays, it is customary to provide high-head sluice gates with breast wall for periodic flushing out of sediments from the reservoir), it is preferred to provide curved glacis

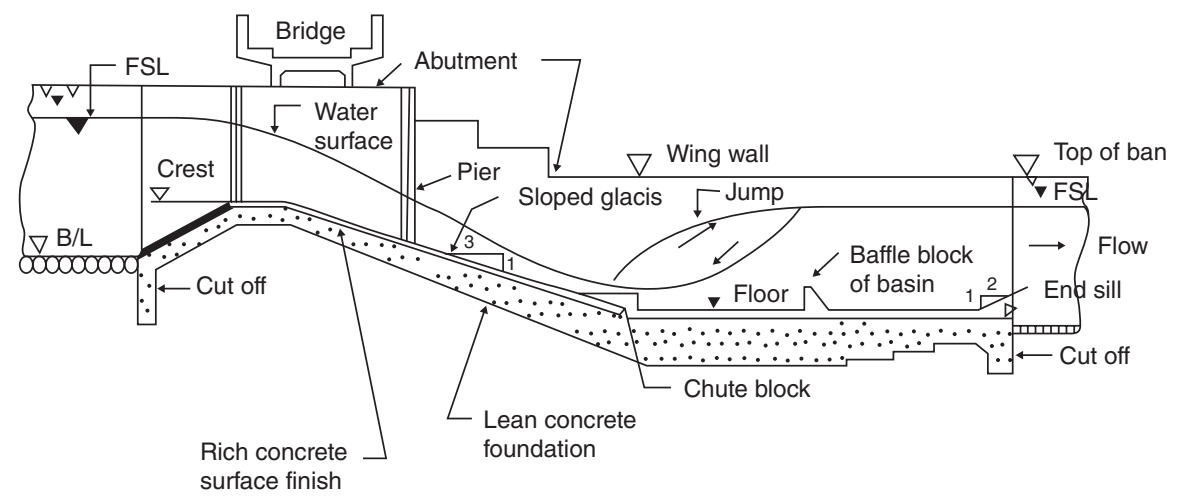

FIGURE 1.7

Inclined straight glacis-type canal drop. 
downstream so that the flow does not separate. With full head on the gate and with small opening under the gate (say $1 \mathrm{~m}$ ), a freely discharging trajectory will follow the path of a jet issuing from an orifice. For an orifice with vertical face, the path followed by the issuing jet is parabolic and is given by the relation

$$
-\mathrm{y}=\mathrm{x}^{2} / 4 \mathrm{H}
$$

where $\mathrm{H}$ is the head measured from the center of the gate opening up to the full reservoir level. For an orifice face inclined at an angle $\theta$ with vertical, the equation for the trajectory will be

$$
-y=x \tan \theta+x^{2} / 4 H \cos ^{2} \theta
$$

If the spillway profile does not conform to the jet trajectory as above, a subatmospheric pressure will arise and cavitation damage will occur. Figure 1.8
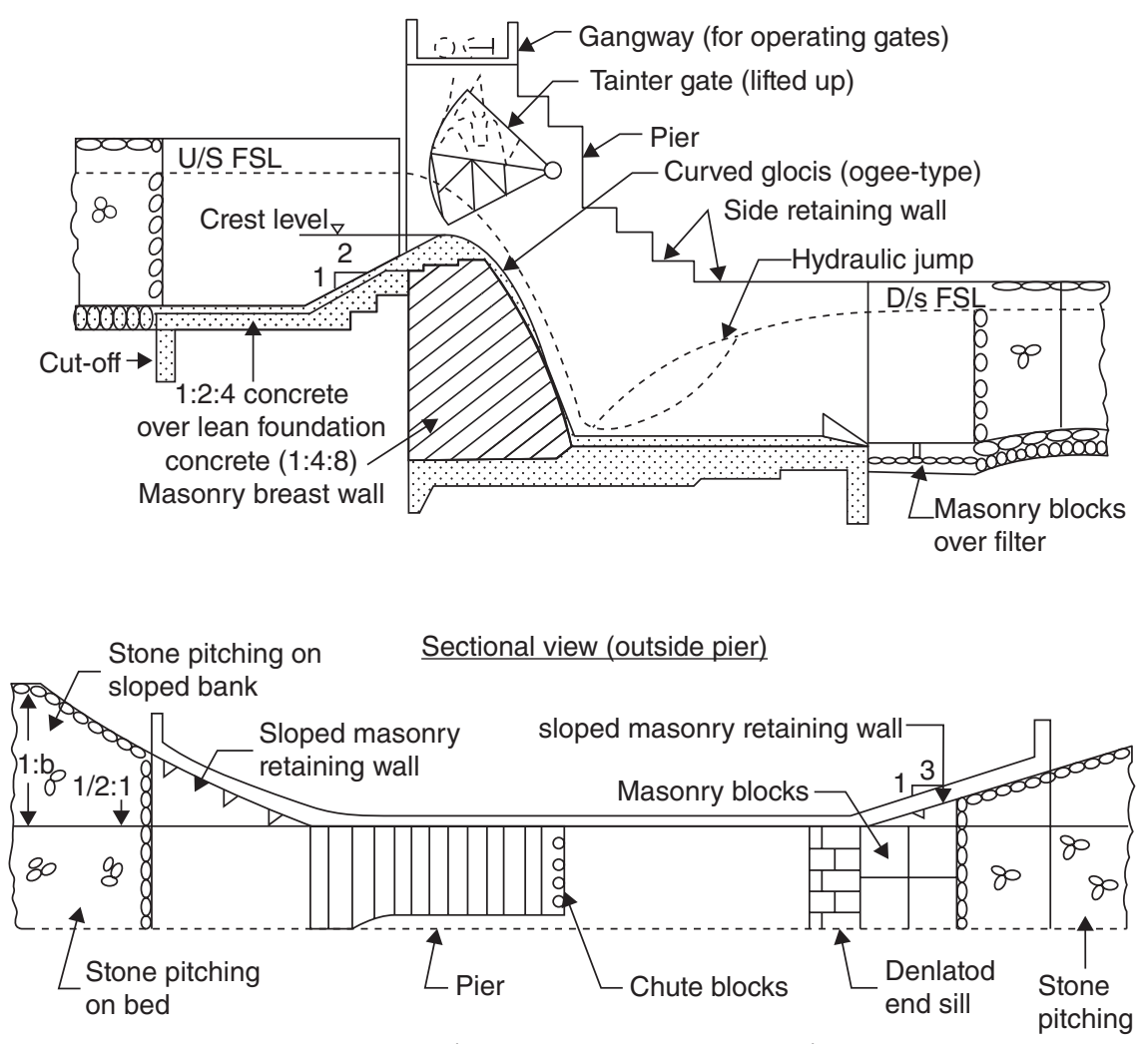

Hall plan (gates and gangway removed)

\section{FIGURE 1.8}

Flumed canal drop with Creager-type curved glacis with radial gate, stilling basin, and inlet and outlet transitions. 


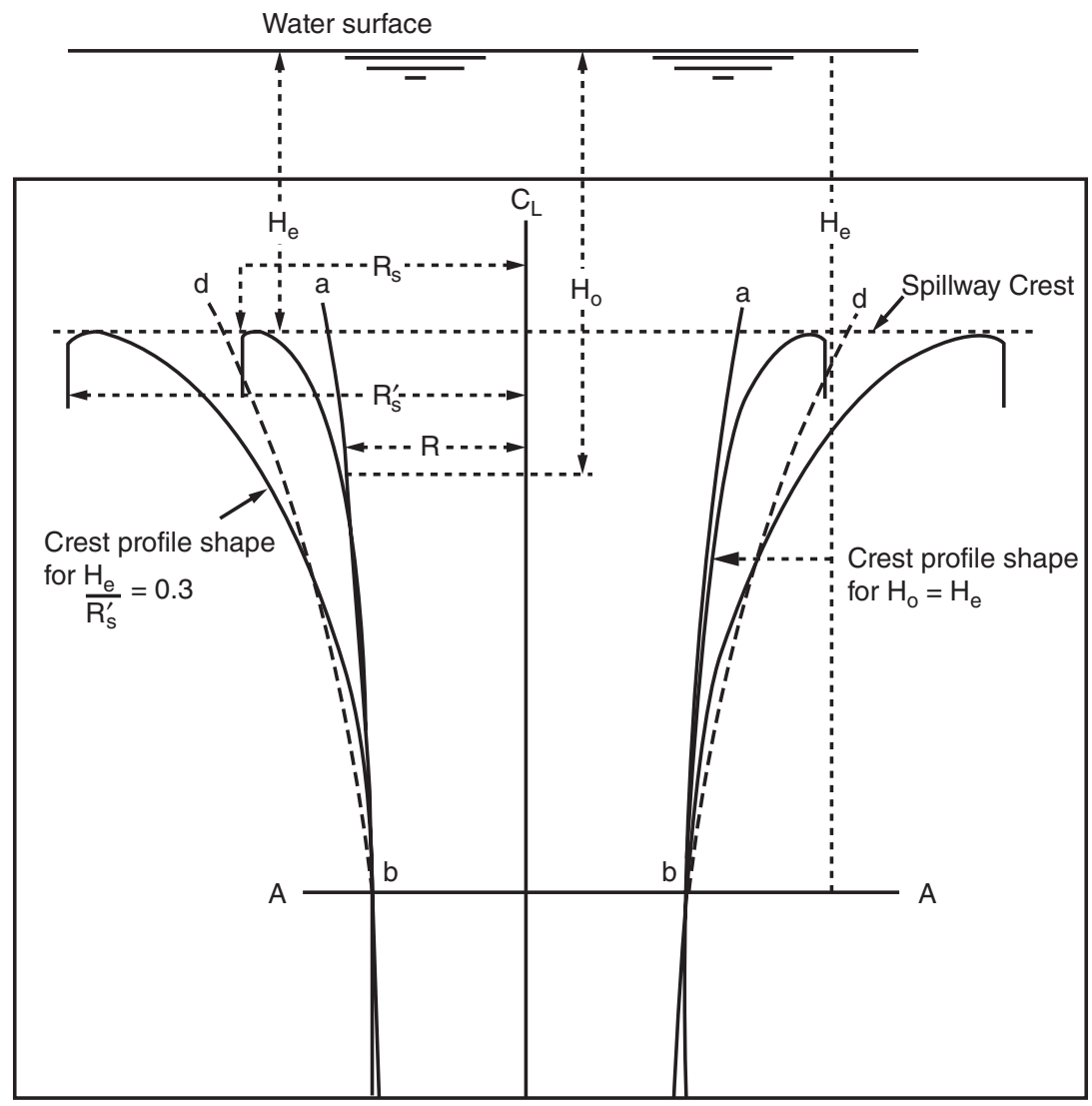

FIGURE 1.9

Shaft-type spillway. (With permission from US Bureau of Reclamation, 1974. Design of Small Dams by Oxford and IBH Publishing House: Calcutta, Bombay, New Delhi.)

illustrates a drop structure with Creager-type ogee spillway mounted with radial-type gate.

In case of shaft spillway, supercritical transition connects a circular funnel at entry (control section) with a circular conduit as illustrated in Figure 1.9. USBR (1968) and Peterka (1956) provide the coordinates for the transition profile based on the experimental data by Wagner (1956). Further details of such transition in a shaft spillway will be discussed in Chapters 2 and 3.

\subsubsection{Transition from Supercritical to Subcritical Flow}

Transition from supercritical to subcritical flow without any jump is theoretically possible by providing a streamlined wedge-shaped structure (CBIP Publication No.6) such that the specific energy changes gradually, and there is no flow separation from the boundary. Abdorreza et al. (2014) developed 
the streamlined aerofoil-shaped surface profile for conversion of an incoming supercritical to a subcritical flow without forming a hydraulic jump. However, as the discharge changes from the design value, the flow separates resulting in the formation of hydraulic jump accompanied by energy loss.

Hydraulic jump is a means through which an incoming supercritical flow changes to subcritical flow. Flow downstream of a dam/weir, a canal drop, or a flow meter becomes supercritical as it moves over the spillway/glacis. If the supercritical flow continues, it will cause erosion of channel bed and banks, eventually leading to failure of such structures. Hydraulic jump occurs when an incoming supercritical flow meets an outgoing subcritical flow as illustrated in Figures 1.7 and 1.10. Hydraulic jump is a natural means of energy dissipation. The structure in which hydraulic jump and consequent energy dissipation occur is designated as stilling basin or energy dissipater. Stilling basin (Bradley and Peterka, 1957) acts as a transition structure where the flow changes from a supercritical high-velocity flow to a subcritical lowvelocity flow. The basin must be carefully designed to ensure that there is no residual kinetic energy of flow after the exit end of the basin.

Classical stilling basins with free and forced jump conditions (by using different kinds of appurtenances) for different inflow Froude's numbers were developed by Bradley and Peterka (1957), Hager (1992), Pillai and Unny (1964), Rajaratnam (1967), Rand (1965), Rhebock (1928), Tamura (1973), USBR (1987), and many others (Hager,1992). More information on hydraulic jump characteristics and design of stilling basins is discussed in Chapters 2 and 3. An illustrative example of designing a forced hydraulic jump-type stilling basin is worked out in Chapter 5 .

\subsubsection{Transition from Supercritical to Supercritical Flow}

Supercritical flow in open channel is highly prone to disturbances. Shock waves (Photo 1.1) occur when a supercritical flow with parallel streamlines flowing in a prismatic channel with parallel side walls is made to change its direction due to imposition of either a contracting or an expanding boundary or change in slope in bed. When the flow is steady, the shock waves look almost like a hydraulic jump accompanied with sudden rise in water surface. However, the fundamental difference between a hydraulic jump and a

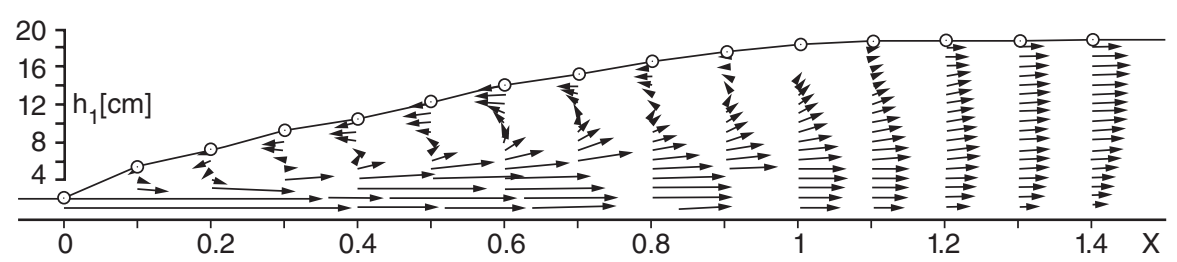

FIGURE 1.10

Classical hydraulic jump where flow changes from a supercritical to a subcritical state. 


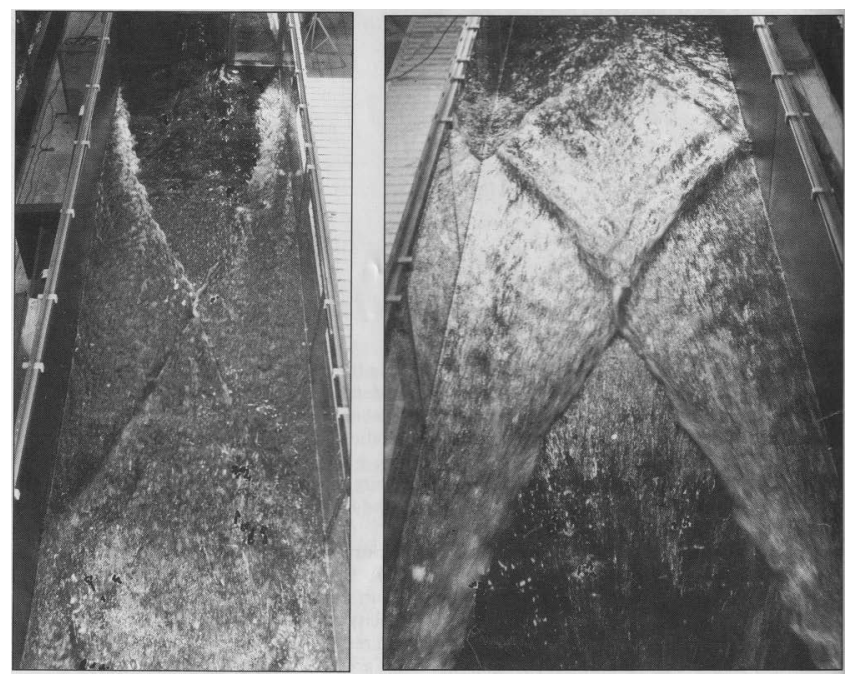

\section{PHOTO 1.1}

Shock waves in supercritical flow after sudden expansion. (Reprinted from Hager \& Mazumder, 1992.)

shock wave is that a hydraulic jump is always associated with energy dissipation; but in shock wave, there is practically no energy loss. There is always a change in flow regime from a supercritical to a subcritical state in a jump. In a shock wave, on the other hand, flow before and after the shock front remains supercritical.

The design of transitions in a supercritical transition aims at suppressing or at least reducing the shock waves in order to

a. Make the flow uniform

b. Avoid flow concentrations

c. Provide adequate freeboard in structures

d. Inhibit spray formation

e. Suppress local jump formation

Studies on the characteristics of shock waves in hydraulic structures were carried out by Schoklitsch (1937), Ippen (1950), Knapp and Ippen (1938), Von Karman (1938), Ippen and Dawson (1951), Ippen and Harleman (1956), Chow (1973), Hager and Mazumder (1992), and Mazumder and Hager (1993). Design of contracting and expanding transitions in supercritical flow was carried out by Ippen and Dawson (1951), Rouse et al. (1951), and Rouse (1950), respectively. Dakshinamoorthy (1977), Hager and Mazumder (1992), and Mazumder and Hager (1993) conducted an exhaustive experimental study 
on supercritical flow expansions. Mazumder and Hager (1995) compared the performance of different types of chute expansions with and without appurtenances for finding the optimum axial length of expansions. Mazumder et al. (1994) also developed methods for controlling shock waves in supercritical flow expansions. Further details about the characteristics of flow and transition design in supercritical flow are provided in Chapters 2, 3, and 5.

\subsubsection{Closed Conduit Pressure Flow Transition}

For pressure flow in closed conduits, both contracting and expanding transitions are to be provided whenever there is a change in cross section as in venturi meters, control valves, entrance to Head Race Tunnel (HRT) in hydel plant, de-sedimentation chamber, draft tube in reaction turbines, etc. Since contraction of flow is associated with a negative or favorable pressure gradient, the flow is stable. In flow expansion as in a diffuser, however, the flow is under an adverse or positive pressure gradient, and as such, the flow is unstable, and it may separate from the boundary if the angle of divergence exceeds a critical value of about $5^{\circ}-6^{\circ}$. For example, in a Herschel-type venture meter, the total angle of inlet cone of contracting transition is kept about $20^{\circ}$, whereas the total angle of diverging cone is limited to about $5^{\circ}$ only in order to prevent flow separation and to minimize head loss. Usually, a venture meter has a fluming ratio $\left(\mathrm{D}_{2} / \mathrm{D}_{1}\right)$ of about 0.5 . When the fluming ratio is very low as in case of outlet from a tank or a reservoir, the entrance transition should be streamlined to provide a smooth and gradual entrance to the conduit. As in a nappe-shaped spillway, the entry should guide and support the jet with minimum interference until it is contracted to the size of the conduit. In case the entrance transition is too sharp or too short, a subatmospheric pressure will develop resulting in cavitation damage to the conduit. For a circular conduit, a bellmouth-type entrance contracting transition is normally made elliptic in shape with coordinates $(x, y)$ of the boundary surface given by the equation

$$
x^{2} /\left(0.5 D^{2}\right)+y^{2} /\left(0.15 D^{2}\right)=1
$$

where $\mathrm{D}$ is the diameter of the conduit, and $0.5 \mathrm{D}$ and $0.15 \mathrm{D}$ are the lengths of semimajor and semiminor axes, respectively. For a rectangular conduit, similar equation is applicable with the difference that the lengths of semimajor and semiminor axes are given by $\mathrm{D}$ and $0.33 \mathrm{D}$, respectively. For a rectangular entrance with the bottom placed with the upstream floor and with curved guide piers at each side of the entrance, both the side and top contracting transitions are also made elliptical with $\mathrm{D}$ and $0.67 \mathrm{D}$ being semimajor and semiminor axes, respectively.

To minimize head loss and to avoid cavitation along the conduit surface, straight contraction to a gate control section, and straight expansion from the gate section back to conduit section, the total angle of converging duct $\left(\alpha_{\mathrm{u}}\right)$ 
and that of the diverging duct $\left(\alpha_{d}\right)$ should not exceed a limiting value given by the following equations, respectively:

$$
\begin{aligned}
& \tan \alpha_{\mathrm{u}}=1 / \mathrm{F} \\
& \tan \alpha_{\mathrm{d}}=1 / 2 \mathrm{~F}
\end{aligned}
$$

where $F=V_{a v} / \sqrt{ }(g D)$ with $V_{a v}$ being the mean of the velocities at the normal and control sections, respectively (USBR, 1968).

In all reaction-type turbines (e.g. Francis, Kaplan, Bulb, and Tubular), draft tubes are essentially provided for conversion of kinetic energy of flow leaving the turbines to pressure head so that the efficiency of turbines increases. Without a well-designed draft tube, especially in low and medium head turbines, the kinetic energy head is lost in turbulence and the overall efficiency of turbine will decrease.

Draft tubes are flow diffusers subject to positive or adverse pressure gradient which is responsible for separation and instability of flow. Gibson (1910, 1912) studied head loss in both converging and diverging ducts to find the efficiency of both confusers and diffusers. The optimum total angle of circular and square diffusers was found to be $8^{\circ}$ and that for a rectangular duct was $11^{\circ}$. A similar study on diffuser flow characteristics was conducted by Robertson and Ross (1951, 1953, 1957), Robertson and Fraser (1959), Nikuradse (1929), Gourzhienko (1947), Kalinske (1945), Formica (1955), Tults (1954), and others (Pradtl and Tietzens, 1957; Schlichting, 1958, 1962). Kline et al. (1959) conducted an exhaustive study on the optimum design of two-dimensional straight-walled diffusers. Cochran and Kline (1958) used rectangular flat vanes for producing efficient wide-angle two-dimensional subsonic diffusers.

In wind tunnels used for the aerodynamic study, a warped-type contracting transition (with an average side splay of 2:1) connects the square section of large honeycombed area at the entrance with the test section, and a conical diffuser connects the test section with a large exit diameter. It is necessary to provide a suitable transition to convert the rectangular/square test section to a circular section of equivalent area before the entry to a circular diffuser. Further details about flow characteristics and design of diffusers are provided in Chapters 2 and 3.

\section{References}

Abdorreza, K., Samani, M.H., Rabieihamidreza, S.M.B. (2014). “Experimentalanalytical investigation of super-to subcritical flow transition without a hydraulic jump," Journal of Hydraulic Research, IAHR, Vol. 52, No. 1, pp. 129-136. 
Ackers, P., White, W.R., Perkins, J.A., Harrison, A.J.M. (1978). “Weirs and Venturi Flumes for Flow Measurement," John Wiley \& Sons, Inc., New York.

Ahuja, K.C. (1976). "Optimum Length of Contracting Transition in Open-Channel Sub-Critical Flow," M.Sc. (Engg) Thesis submitted to the Delhi University.

Blaisdel, F.W. (1954). "Equation of the free-falling nappee," Proceedings of ASCE, Vol. 80, Separate no. 452, p. 16.

Bos, M.G. (1975). "Discharge Measurement Structures," Oxford \& IBH Publishing Co, New York.

Bradley, J.N. (1970). "Hydraulics of Bridge Waterways," Federal Highway Administration, Hydraulic Design Series No. 1.

Bradley, J.N., Peterka, A.J. (1957). "The hydraulic design of stilling basins," Journal of the Hydraulics Division, Proceedings of ASCE, Vol. 83, No. HY5, Papers Nos. 1401-1406, Inclusive. pp. 1-32.

CBIP (1957). "Fluming," Published by the Central Board of Irrigation and Power, Publication No. 6, 1934 (revised in 1957).

Chaturvedi, R.S. (1963). "Expansive sub-critical flow in open channel transitions," Journal of The Institution of Engineers (India), Vol. 43, No. 9, p. 447.

Chow, V.T. (1973). "Open Channel Hydraulics," McGraw-Hill International Book Co, New Delhi.

Cochran, D.L., Kline, S.J. (1958). "The Use of Short Flat Vanes for Producing Efficient Wide-Angle Two-Dimensional Sub-Sonic Diffusers," NACA Technical Note, 4309.

Creager, W.P., Justin, J.D. (1950). "Hydro-Electric Handbook," 2nd Ed., pp. 302-363, John Wiley \& Sons, Inc., New York.

Dakshinamurthy (1977). "High Velocity Flow through Expansions," Proceedings of XXII IAHR Congress, Baden-Baden, pp. 373-390.

Deb Roy, I. (1995). "Improved Design of a Proportional Flow Meter," M.E. Thesis submitted to the Department of Civil Engineering, Delhi College of Engineering, December 1995, under the guidance of Prof. S.K. Mazumder.

Formica, G. (1955). “Esperiense Preliminari Sulle Perdite di carico, nei canali, Dovute a Cambiamenti di Sezione," L'Energia Elettrica, Milano, Vol. 32, No. 7, pp. 55-56.

Gibson, A.H. (1910). "On the flow of water through pipes having converging or diverging boundaries," Proceedings of the Royal Society of London, Series A, Vol. 83, p. 366.

Gibson, A.H. (1912). "Conversion of kinetic to potential energy in the flow of water through passage having diverging boundaries," Engineering, Vol. 93, p. 205.

Gourzhienko, G.L. (1947). "Turbulent Flow in Diffuser of Small Divergence Angle," Report 462, Central Aero-Hydro-Dynamical Institute, Moscow, Transactions of NACA, TM 1137.

Hager, W.H. (1992). "Energy Dissipators and Hydraulic Jump," Kluwer Academic Publishers, London.

Hager, W.H., Mazumder, S.K. (1992). "Super-Critical Flow at Abrupt Expansions," Proceedings of the Institution of Civil Engineers on Water, Maritime E Energy, London, September, Vol. 96, No. 3, pp. 153-166.

Hinds, J. (1928). "Hydraulic design of flume and syphon transitions," Transactions of ASCE, Vol. 92, pp. 1423-1459.

Hinds, J., Creager, W.P., Justin, J.D. (1945). "Engineering for Dams," Vol. 2, pp. 358-361, John Wiley and Sons, Inc., New York.

Ippen, A.T. (1950). "Channel transitions and controls," Chapter VIII in Engineering Hydraulics. Ed. H. Rouse, John Wiley \& Sons, Inc., New York, pp. 496-588. 
Ippen, A.T., Dawson, J.H. (1951). "Design of Channel Contractions," 3rd Paper in High Velocity Flow in Open Channels: A Symposium, Transactions of ASCE, Vol. 116, pp. 326-346.

Ippen, A.T., Harleman, D.R.F. (1956). "Verification of theory for oblique standing waves," Transactions of ASCE, Vol. 121, pp. 678-694.

IS:6062 (1986). "Flow Measurement by Standing Wave Flumes," Bureau of Indian Standard, New Delhi.

Ishbash, S.V., Lebedev, I.V. (1961). "Change in Natural Streams during Construction of Hydraulic Structures," Proceedings of IAHR, Ninth Convention, Dubrovink, Yugoslovia, September 4-7, 1961.

Jaeger, C. (1956). "Engineering Fluid Mechanics," 1st Ed., Blackie and Sons, London.

Kalinske, A.A. (1945). "Conversion of kinetic to potential energy in flow expansion," Transactions of ASCE, Vol. 3, pp. 355-390 (Proceedings of ASCE, December 1944, p. 1545).

Kline, S.J., Abott, D.E., Fox, R.W. (1959). “Optimum design of straight walled diffusers," Journal of Basic Engineering, Transactions of ASME, Vol. 81321.

Knapp, R.T., Ippen, A.T. (1938). "Curvilinear Flow of Liquids with Free Surfaces at Velocities above that of Wave Propagation," Proceedings of 5th International Congress of Applied Mechanics, Cambridge, MA, John Wiley \& Sons, Inc., New York, pp. 531-536.

Kulandaiswami, U.C. (1955). "Transition for Sub-Critical Flow in Open Channels," M.Tech. Thesis Submitted to the Department of Civil Engineering, IIT, Kharagpur.

Lagasse, P.F., Schall, F., Johnson, E.V., Richardson, E.V., Chang, F. (1995). "Stream Stability at Highway Structure," Department of Transportation, Federal Highway Administration, Hydraulic Engineering Circular No. 20, Washington, DC.

Mazumder, S.K. (1966a). "Limit of submergence in critical flow meters," Journal of Institution of Engineer (India), Vol. IXV, No. 7.

Mazumder, S.K. (1966b). "Open Channel Expansion in Sub-Critical Flow," M.Tech. Thesis submitted to the IIT, Kharagpur.

Mazumder, S.K. (1967). “Optimum length of transition in open-channel expansive sub-critical flow," Journal of Institution of Engineers (India), Vol. XLVIII, No. 3, pp. 463-478.

Mazumder, S.K. (1969). “Design of Wide-Angle Open-Channel Expansion in SubCritical Flow by Control of Boundary Layer Separation with Triangular Vanes," Ph.D. Thesis submitted to the Department of Civil Engineering, IIT (Kharagpur) under the guidance of Prof. J.V. Rao, July 1969.

Mazumder, S.K. (1971). “Design of Contracting and Expanding Transition in Open Channel Flow," 41st Annual Research session of CBIP, Jaipur, July 1971, Vol. 14, Hydraulic Publication No. 110.

Mazumder, S.K. (2010). "Behavior and Training of River Near Bridges and BarragesSome Case Study," Paper Presented and Published in the International Conference on River Management-IWRM-2010, Organized by IWRS and WRDM, IIT, Roorkee, and held at New Delhi, December 14-16.

Mazumder, S.K., Deb Roy, I. (1999). "Improved design of a proportional flow meter," ISH Journal of Hydraulic Engineering, Vol. 5, No. 1. pp. 295-312.

Mazumder, S.K., Dhiman, R. (2003). "Computation of Afflux in Bridges with Particular Reference to a National Highway," Proceedings of HYDRO-2003, Pune (CWPRS), December 26-27. 
Mazumder, S.K., Hager, W. (1993). "Supercritical expansion flow in rouse modified and reversed transitions," Journal of Hydraulic Engineering, ASCE, Vol. 119, No. 2, pp. 201-219.

Mazumder, S.K., Hager, W. (1995). "Comparison between various chute expansions," Journal of the Institution of Engineers (India). Civil Engineering Division, Vol. 75. pp. 186-192.

Mazumder, S.K., Rao, J.V. (1971). “Use of short triangular vanes for efficient design of wide-angle open-channel expansions," Journal of Institution of Engineers (India), Vol. 51, No. 9. pp. 263-268.

Mazumder, S.K., Sinnigar, R., Essyad, K. (1994). “Control of shock waves in supercritical expansions," Journal of Irrigation \& Power by CBI \& P, Vol. 51, No. 4. pp. 7-16.

Mazumder, S.K., Rastogi, S.P., Hmar, R. (2002). "Restriction of waterway under bridges," Journal of Indian Highways, Vol. 30, No. 11. pp. 39-50.

Mitra, A.C. (1940). “On Hyperbolic Expansions," Technical Memorandum No 9, UP Irrigation Research Station, Roorkee.

Nasta, C.F., Garde, R.J. (1988). "Sub-critical flow in rigid bed open channel expansions," Proceedings of ASCE, JHD, Vol. 26.

Nikuradse, J. (1929). "Untersuchungenten Uber die Stromungen des Wassers in Convergenten und Divergenten Kanalen," Forschunsarbeitten deutscher Ingenieure, Heft, 289.

Parshall, R.L. (1926). "The improved venture flume," Proceedings of ASCE, Vol. 89, Paper no. 1956. pp. 841-851.

Parshall, R.L. (1950). "Measuring Water in Irrigation Channels with Parshall Flumes and Small Weirs," Circular (U.S. Soil Conservation), no. 843.

Peterka, A.J. (1956). "Morning glory shaft spillways," Transactions of ASCE, Vol. 121, p. 385.

Peterka, A.J. (1957). "The hydraulic design of stilling basins," Journal of Hydraulics Division, Vol. 93, No. HY5, Papers Nos. 1401-1406.

Pillai, N., Unny, T.E. (1964). "Shapes of appurtenances in stilling basin," Journal of the Hydraulics Division, Proceedings of ASCE, Vol. 90, No. HY3, pp. 1-21, discussions 1964, 90 (HY6): 343-347, 91 (HY1): 164-166, 1965, 91 (HY5): 135-139.

Prandtl, L., Tietzens, O.G. (1957). "Applied Hydro and Aerodynamics" (translated by Rozenhead), Denver Publications, Denver, CO.

Rajaratnam, N. (1967). "Hydraulic jumps," Advances in Hydroscience, Vol. 4, pp. 197-280, Ed. V.T. Chow, Academic Press, New York.

Ramamurthy, A.S., Basak, A.S., Rama, R. (1970). “Open channel expansions fitted with local hump," Journal of the Hydraulics Division. Proc. ASCE, May.

Rand, W. (1965). "Flow over a vertical sill in an open channel," Journal of the Hydraulics Division, Proceeding of ASCE, Vol. 91, No. HY4, pp. 97-121.

Rao, J.V. (1951). "Exit Transitions in Cross-Drainage Works-Basic Studies," Irrigation Research Station, Poondi, Madras, Ann. Research Publication No. 8.

Rhebock, T. (1928). "Die Verhutung schadlicher Kolke BeiSturzbetten," Schweweizersch wasserwirtschaft, Vol. 20, No. 3, pp. 35-40; Vol. 20, No. 4, pp. 53-58.

Robertson, J.M., Fraser, H.R. (1959). "Separation prediction for conical diffusers," Journal of Basic Engineering, Transactions of ASME, Paper no. 59.

Robertson, J.N., Ross, D. (1951). "A superposition analysis of turbulent boundary layer in an adverse pressure gradient," Journal of Applied Mechanics, Transactions of ASME, Vol. 18, pp. 95-100. 
Robertson, J.N., Ross, D. (1953). "Effect of entrance conditions on diffuser flow," Transactions of ASCE, Vol. 118, pp. 1063-1097.

Robertson, J.M., Ross, D. (1957). "Performance characteristics of a 48-in water tunnel," Engineering, Vol. 184, pp. 76-80.

Robertson, J.M., Ross, D. (1957). “Water Tunnel Diffuser Flow Studies” Part-I: 'Review of Literature', Part-II: Experimental Research', Part-III: 'Analytical Research', Ordnance Research Laboratory, Pennsylvania State College, School of Engineering, University Park, PA.

Rouse, H. (1950). "Engineering Hydraulics," John Wiley \& Sons Inc., New York.

Rouse, H., Bhoota, B.V., Hsu, E.Y. (1951). "Design of Channel Expansions," 4th Paper in High Velocity Flow in Open Channels: A Symposium, Transactions of ASCE, Vol. 116, Paper no. 2434, pp. 326-346.

Schlichting, H. (1958). "Some Recent Developments in Boundary Layer Control," Paper Presented at the First International Congress of the Aeronautical Sciences, Madrid.

Schlichting, H. (1962). "Boundary Layer Theory," Translated in English by J. Kestin, pp. 891-892, McGraw-Hill Book Co., Inc., New York.

Schoklitsch, A. (1937). "Hydraulic Structures," Vol. 2, Translated from the German by Samuel Shulits, ASME, New York.

Schoklitsch, A. (1950). "Handbook of Hydraulic Engineering," Vol. 1, pp. 122-124, Springer-Verlag, Vienna.

Simons Jr, W.P. (n.d.). "Hydraulic Design of Transitions for Small Canals," Engineering Monograph No 33. Published by the US Department of Interior, Bureau of Reclamation.

Smith, C.D., Yu James, N.G. (1966). "Use of baffles in open channel expansion," Journal of the Hydraulics Division, ASCE, Vol. 92, No. 2, pp. 1-17.

Swamee, P.K., Basak, B.C. (1991). “Design of rectangular open channel expansion transitions," Journal of Irrigation and Drainage Engineering, ASCE, Vol. 117, No. 6.

Tamura, M. (1973). “Designs and Hydraulic Model Investigation of Hydraulic Jump Type Dissipaters," XI ICOLD Congress, Madrid, Q41, R26, pp. 471-488.

Tults, H. (1954). "Flow expansion and pressure recovery in fluids," Proceedings of ASCE, Vol. 80, Paper no. 567.

USBR (1952). "Hydraulic design data: Appendix-I of canals and related structures," Design and Construction Manual, Design Supplement No.3, Vol. X, pt. 2, pp. 1-13.

USBR (1968). "Design of Small Dams," Indian Edition, Oxford \& IBH Publishing Co., Kolkata.

USBR (1987). "Design of Small Dams," 3rd Ed., Department of Interior, Denver, CO.

Von Karman, T. (1938). "A practical application of analogy between supersonic flow in gases and super-critical flow in open channels," Zeitschrift fur Angewandte Mathematik and Mechanik, Berlin, Vol. 18, pp. 49-56.

Vittal, N., Chiranjivi, V.V. (1983). “Open-channel transition: Rational method of design," Journal of the Hydraulics Engineering, ASCE, Vol. 109, No. 1, pp. 99-115.

Wagner, W.E. (1956). "Morning glory shaft spillways: Determination of pressure controlled rifles," Transactions of ASCE, Vol. 121, p. 345.

Abdorreza, K., Samani, M.H., Rabieihamidreza, S.M.B. (2014). "Experimentalanalytical investigation of super-to subcritical flow transition without a hydraulic jump," Journal of Hydraulic Research, IAHR, Vol. 52, No. 1, pp. 129-136.

Ahuja, K.C. (1976). "Optimum Length of Contracting Transition in Open-Channel Sub-Critical Flow," M.E. Thesis submitted to the Department of Civil Engineering, Delhi University. 
Bakhmeteff, B.A., Matzke, A.E. (1936). “The hydraulic jump in terms of dynamic similarity," Transactions of ASCE, Vol. 101, pp. 630-647.

Bhargava, Praveen (1981), "Studies on Flow Characteristics in Wide-Angle Diffuser Provided With Appurtenances," M.E. Thesis submitted to Delhi University, Department of Civil Engineer, Delhi College of Engineering, September.

Bidone, G. (1819). “Observations Sur Le Hauteur du Ressaut Hydraulique en 1818 (Observations on the Height of Jump in 1818)," A Report Presented at the Meeting of Royal Academy of Sciences of Turin, pp. 21-80.

Blaisdel, F.W. (1948). "Development and hydraulic design, Saint Anthony Falls stilling basin," Transactions of ASCE, Vol. 113, pp. 483-520.

Bradley, J.N., Peterka, A.J. (1957). "The hydraulic design of stilling basins, hydraulic jump on horizontal apron," Journal of the Hydraulics Division, Proceedings of ASCE, Vol. 83, No. HY5, Paper No. 1401-1406, pp. 132.

CBIP (1957). "Fluming." Publication no. 6, 1934 (revised in 1957) Published by the Central Board of Irrigation and Power, Chanakyapuri, Malcha Marg, New Delhi.

Chanson, H. (1993), "Stepped spillway flows and air entrainment," Canadian Journal of Civil Engineering, Vol. 20, No. 3.

Chow, V.T. (1973). "Open Channel Hydraulics," McGraw-Hill International Book Co, New Delhi.

Corry, M.L., Thompson, P.L., Watts, E.J., Jones, J.S., and Richards, D.L. (1975) “Hydraulic Design of Energy Dissipators for Culverts and Channels," Engineering circular 145, Federal Highway Administration, U.S. Department of Transportation, Washington, DC.

Hager, W.H. (1992a). "Energy Dissipators and Hydraulic Jump," Kluwer Academic Publishers, London.

Hager, W.H. (1992b), "Spillways, Shockwaves and Air Entrainment," ICOLD Bulletin, 1981, Commission Internationale des Grands Barrages, Paris, France.

Hager, W.H., Mazumder, S.K. (1993). "Flow choking in an expanding bucket," International Journal of Water Power E Dam Construction, pp. 50-52.

Haeger, W.H., Mazumder, S.K. (1992). "Super-Critical Flow at Abrupt Expansions," Proceedings of the Institution of Civil Engineers on Water, Maritime E Energy, London, September, Vol. 96, No. 3, pp. 153-166.

Hinds, J. (1928) "Hydraulic Design of Flume and Syphon Transitions," Trans. ASCE, Vol. 92, pp. 1423-1459.

Ippen, A.T., Dawson, J.H. (1951). "Design of channel contraction," High Velocity Flow in Open Channel (Symposium), Transactions of ASCE, Vol. 116, pp. 326-346.

Ishbash, S.V., Lebedev, I.V. (1961). "Change of Natural Streams during Construction of Hydraulic Structures," Proceedings of IAHR, Ninth Convention, Dubrovink, Yugoslovia, September 4-7, 1961.

Joshi, L.M. (1979). "Limit of Submergence in Critical Flow Meters," M.E. Thesis Submitted to the Department of Civil Engineering, Delhi College of Engineering.

Kline, S.J., Abott, D.E., Fox, R.W. (1959). "Optimum design of straight walled diffusers," Journal of Basic Engineering, Transactions of ASME, Vol. 81, 321.

Mazumder, S.K. (1966). "Studies on Energy Loss for Optimum Length of Transitions in Open Channel Expansion," M.Tech. Thesis submitted to the Department of Civil Engineering, IIT, Kharagpur.

Mazumder, S.K. (1967). “Optimum length of transition in open-channel expansive sub-critical flow," Journal of Institution of Engineers (India), Vol. XLVIII, No. 3, pp. $463-478$. 
Mazumder, S.K. (1970). "Design of Wide-Angle Expansions in Sub Critical Flow by Control of Boundary Layer Separation with Triangular Vanes," Ph.D. Thesis submitted to the Department of Civil Engineering, IIT, Kharagpur.

Mazumder, S.K. (1971). "Design of Contracting and Expanding Transition in Open Channel Flow," 41st Annual Research session of CBIP, Jaipur, July 1971, Vol. 14, Hydraulic Publication No. 110.

Mazumder, S.K. (2000). "Role of Farakka Barrange on the Disastrous Flood at Malda (West Bengal) in 1998," Proceedings of 8th ICID International Drainage Workshop, Role of Drainage and Challenges in 21st Century, Vol. II, Sponsored by ICID-CIID, \& MOWR, Organized by ICD \& WAPCOS, New Delhi, 31st January-4th February 2000.

Mazumder, S.K., Ahuja, K.C. (1978) "Optimum length of contracting transition in open channel sub critical flow" J1. Of CE Div., Institute of Engineers (1), Vol. 58, pt CI-5, March 78.

Mazumder, S.K., Deb Roy, Indraneil (1999) "Improved Design of a Proportional Flow Meter" ISH Journal of Hydraulic Engineering, Vol. 5, No. 1.

Mazumder, S.K., Hager, W.H. (1993). "Supercritical expansion flow in rouse modified and reversed transitions," Journal of Hydraulic Engineering, ASCE, Vol. 119, No. 2, pp. 201-219.

Mazumder, S.K., Hager, W.H. (1995). “Comparison between various chute expansions," Journal of the Institution of Engineers (India). Civil Engineering Division, Vol. 75. pp. 186-192.

Mazumder, S.K., Kumar, P. (2001). "Sub-critical flow behavior in a straight expansion," ISH Journal of Hydraulic Engineering, Indian Society for Hydraulics, Vol. 7, No. 1.

Mazumder, S.K., Rao, J.V. (1971). “Use of short triangular vanes for efficient design of wide-angle open-channel expansions," Journal of Institution of Engineers (India), Vol. 51, No. 9, pp. 263-268.

Mazumder, S.K., Sinnigar, R., Essyad, K. (1994). "Control of shock waves in supercritical expansions," Published in the Journal of Irrigation \& Power by CBI \& P, Vol. 51, No. 4. pp. 7-16

Pfister, M., Hager, W.H., Minor H.E. (2006). "Bottom aeration of stepped spillways," Journal of Hydraulic Engineering, Vol. 132, No. 8.

Prndtl, L., Tietzens, O.G. (1957). "Applied Hydro and Aerodynamics" (Translated by Rozenhead), Denver Publications, Denver, CO.

Pramod Kumar (1998) "Some Study on Flow-Stability in an Expansion," Department of Civil Engineer, Delhi University, August 1998.

Rajaratnam, N. (1990). "Skimming flow in stepped spillways," Journal of Hydraulic Engineering, Vol. 116, No. 4.

Ranga Raju, K.G. (1993). "Flowthrough Open Channels," Tata Mc-Graw Hill Publishing Co. Ltd., New York.

Rouse, H. (1950). "Engineering Hydraulics," John Wiley \& Sons, Inc., New York.

Rouse, H., Bhoota, B.V., Hsu, E.Y. (1951). "Design of Channel Expansions," 4th Paper in High Velocity Flow in Open Channels: A Symposium, Transactions of ASCE, Vol. 116, Paper no. 2434, pp. 347-363.

Rouse, H., Siao, T.T., Nagaratnam, S., (1958). "Turbulent characteristics of the hydraulic jump," Journal of Hydraulic Division, Proceedings of ASCE, Vol. 84, No. HY1, pp. 1-30.

Safranez, K. (1927). "Computation of expansion of rollers with respect to width of weir" (Hydraulic jump and energy dissipation of water), Wasserkrft und Wasserwirtschft, Der Bauingenieur, Berlin, Vol. 8, No. 49, pp. 808-905; No. 50, p. 926 
Schlichting, H. (1962). "Boundary Layer Theory," Translated in English by J. Kestin, pp. 891-892, McGraw-Hill Book Co., Inc., New York.

Subramanya, K. (1982). "Flow in Open Channels," Vols. I and II, Tata McGraw-Hill Publishing Co. Ltd., New Delhi.

USBR (1968) "Design of Small Dams," Oxford \& IBH Pub. Co., Indian Edition, Kolkata, Mumbai, New Delhi.

Vischer, Daniel L. (1988) "A Design Principle to Avoid Shock Waves in Chutes," The International Symposium for High Dams, Bejing.

Ahuja, K.C. (1976). "Optimum Length of Contracting Transition in Open Channel Sub-Critical Flow," M.Sc. (Civil Engineering) Thesis submitted to the Department of Civil Engineering, Delhi College of Engineering, Delhi University, under the guidance of Prof. S.K. Mazumder.

Asawa, G.L. (1993). "Irrigation Engineering," Wiley Eastern Pvt. Ltd., New Delhi.

Chaturvedi, R.S. (1963). "Expansive sub-critical flow in open channel transitions," Journal of Institution of Engineers (India), Vol. 43, No. 9, p. 447.

Chow, V.T. (1959). "Open Channel Hydraulics," McGraw-Hilal Book Co, New Delhi, London, Panama, Singapore.

Cochran, D.L., Kline, S.J. (1958). "The Use of Short Flat Vanes for Producing Efficient Wide-Angle Two-Dimensional Sub-Sonic Diffusers," NACA Technical Note, 4309.

Creager, W.P., Justin, J.D., Hinds, J. (1968). "Engineering for Dams," Vol. I, Chapter-6, pp. 208-246, Wiley Eastern Pvt. Ltd., New Delhi.

Formica, G. (1955). “Esperiense Preliminari Sulle Perdite di carico, nei canali, Dovute a Cambiamenti di Sezione," L'Energia Elettrica, Milano, Vol. 32, No. 7, pp. 55-56.

Gibson, A.H. (1910). "On the flow of water through pipes having converging or diverging boundaries," Proceedings of the Royal Society of London, Series A, Vol. 83, p. 366.

Gibson, A.H. (1912). "Conversion of kinetic to potential energy in the flow of water through passage having diverging boundaries," Engineering, Vol. 93, p. 205.

Hager, W.H., Mazumder, S.K. (1992). "Abrupt Chute Expansion," Proceedings of Institution of Civil Engineers (London), September, pp. 1535-1566.

Hinds, J. (1928). "Hydraulic design of flume and syphon transitions," Transactions of ASCE, Vol. 92, pp. 1423-1459.

Homma, M., Shima, S. (1952) "On the Flow in a Gradually Divergent Open Channel," The Japan Science Review, series 1, Vol. 2, No. 3, pp. 253-260.

Ippen, A.T. (1951). "Mechanics of super-critical flow," Transactions of ASCE, Vol. 166, pp. $268-295$.

Ippen, A.T., Dawson, J.H. (1951). “Design of Channel Contractions," 3rd Paper in High Velocity Flow in Open Channels: A Symposium, Transactions of ASCE, Vol. 116, pp. 326-346.

Ippen, A.T., Harleman, D.R.F. (1956). "Verification of theory for oblique standing waves," Transactions of ASCE, Vol. 121, pp. 678-694.

Ishbash, S.V., Lebedev, I.V. (1961). "Change in Natural Streams during Construction of Hydraulic Structures," Proceedings of IAHR, Ninth Convention, Dubrovink, Yugoslovia, September 4-7, 1961.

Jaeger, C. (1956). "Engineering Fluid Mechanics," 1st Ed., Blackie and Sons, London.

Kline, S.J., Abott, D.E., Fox, R.W. (1959). “Optimum design of straight walled diffusers," Journal of Basic Engineering, Transactions of ASME, Vol. 81 p. 321.

Mays, L.W. (1999). "Hydraulic Structures Design and Construction Hand Book," by Ben Chie Yen \& A. Osman Khan, McGraw Hill Book Company, New York 
Mazumder, S.K. (1966a). "Studies on Energy Loss for Optimum Length of Transitions in Open Channel Expansion," M.E. Thesis submitted to the Department of Civil Engineering, IIT, Kharagpur.

Mazumder, S.K. (1966b). "Limit of submergence in critical flow meters," Journal of Institution of Engineer (India), Vol. IXV, No. 7.pp. 296-312.

Mazumder, S.K. (1971). "Design of Contracting and Expanding Transition in Open Channel Flow," 41st Annual Research session of CBIP, Jaipur, July 1971, Vol. 14, Hydraulic Publication No. 110.

Mazumder, S.K. (1981a)."Studies of Modular Limit of Critical Flow meter," Proceedings of XIX Congress of IAHR, New Delhi.

Mazumder, S.K. (2007). "Irrigation Engineering," Tata McGraw-Hill Publishing Co. Ltd., New York, 1983 and republished by Galgotia Publications Pvt. Ltd.

Mazumder, S.K., Ahuja, K.C. (1978). “Optimum length of contracting transition in open channel sub critical flow," Journal of the Institution of Engineers (India). Civil Engineering Division, Vol. 58, pt CI-5.

Mazumder, S.K., Joshi, L.M. (1981b). "Studies on critical submergence for flowmeters," Journal of Irrigation \& Power, Vol. 38, No. 2, pp. 175-184.

Mazumder, S.K., Hager, W.H.(1993) "Super-critical expansion flow in rouse modified and reversed transitions," Journal of Hydraulic Engineering, ASCE, Vol. 119, No. 2, pp. 201-213.

Mazumder, S.K., Sinnigar, R., Essyad, K. (1994). "Control of shock waves in supercritical expansions," Journal of Irrigation \& Power by CBI \& P, Vol. 51, No. 4, pp. 7-16.

Mitra, A.C. (1940). “On Hyperbolic Expansions," Technical Memorandum No 9, UP Irrigation Research Station, Roorkee.

Roberson, J.A., Cassidy, J.J., Chaudhry, M.H.(1993).“Hydraulic Engineering," Jaico Publishing House, New Delhi, in arrangement with Houghton Miffin Co., Boston, MA.

Rouse, H., Bhoota, B.V., Hsu, E.Y. (1951). "Design of Channel Expansions," 4th Paper in High Velocity Flow in Open Channels: A Symposium, Transactions of ASCE, Vol. 116, Paper no. 2434, pp. 347-363.

Smith, C.D. (1967). "Simplified design of flume inlets," Hydraulic Division, ASCE, Vol. 93, No. 46.

Smith, C.D., Yu James, N.G. (1966). "Use of baffles in open channel expansion," Journal of the Hydraulics Division, ASCE, Vol. 92, No. 2, pp. 1-17.

USBR (1952)."Hydraulic design data: Appendix-I of canals and related structures," Design and Construction Manual, Design Supplement No.3, Vol. X, pt. 2, pp. 1-13.

USBR (1968). "Design of Small Dams," Indian Edition, Oxford \& IBH Publishing Co., Kolkata.

Vittal, N., Chiranjivi, V.V. (1983). “Open-channel transition: Rational method of design," Journal of the Hydraulics Engineering, ASCE, Vol. 109, No. 1, pp. 99-115.

Wagner, W.E. (1956). "Morning glory shaft spillways: Determination of pressure controlled rifles," Transactions of ASCE, Vol. 121, p. 345.

Bradley, J.N., Peterka, A.J. (1957). "Hydraulic design of stilling basins-stilling basins with sloping apron (basin-V)," Journal of Hydraulics Division, Proceedings of ASCE, Vol. 83, No. HY-5, Paper no. 1405, pp. 1-32; Discussions 1958, Vol. 84, No. HY2, Paper no. 1616, pp. 41-56; 1958; Vol. 84, No. HY-2, Paper no. 1616, pp. 59-75; 1958, No. HY-5, Paper no. 1832, p. 71; 1958, Vol. 84, No. HY-5, Paper no. 1832, pp. 77-81.

Bhargava, P. (1981). "Study of Flow Characteristics in Wide-Angle Diffusers with and without Appurtenances," M.E. Thesis by Praveen Bhargava, Submitted to the 
Delhi College of Engineering, Delhi University, under the guidance of Prof. S.K. Mazumder.

Chaturvedi, M.C. (1963). "Flow characteristics of axis-symmetric expansions," Journal of Hydraulic Division, Proceedings of ASCE, Vol. 89, pp. 61-92.

Chow, V.T. (1973). "Open Channel Hydraulics," McGraw-Hill International Book Co, New Delhi.

Gibson, A.H. (1912).“Conversion of kinetic to potential energy in the flow of water through passage having diverging boundaries," Engineering, Vol. 93, p. 205.

Hager, W.H. (1992). "Energy Dissipators and Hydraulic Jump," Kluwer Academic Publishers, London.

Hager, W.H., Mazumder, S.K. (1992). "Super-Critical Flow at Abrupt Expansions," Proceedings of the Institution of Civil Engineers on Water, Maritime E Energy, London, September, Vol. 96, No. 3, pp. 153-166.

Ippen, A.T., Dawson, J.H. (1951). “Design of channel contraction," High Velocity Flow in Open Channel (Symposium), Transactions of ASCE, Vol. 116, pp. 326-346.

Ishbash, S.V., Lebedev, I.V. (1961). "Change in Natural Streams during Construction of Hydraulic Structures," Proceedings of IAHR, Ninth Convention, Dubrovink, Yugoslovia, September 4-7, 1961.

Kline, S.J., Abott, D.E., Fox, R.W. (1959). "Optimum design of straight walled diffusers," Journal of Basic Engineering, Transactions of ASME, Vol. 81 p. 321.

Mazumder, S.K. (1966). "Design of Wide-Angle Open Channel Expansions in SubCritical Flow by Control of Boundary Layer Separation with Triangular Vanes," Ph.D. Thesis submitted to the IIT, Kharagpur, for the award of Ph.D. degree under the guidance of Prof. J.V. Rao.

Mazumder, S.K. (1967). "Optimum length of transition in open-channel expansive subcritical flow," Journal of Institution of Engineers (India), Vol. XLVIII, No. 3, pp. 463-478.

Mazumder, S.K. (1987). "Stilling Basin with Diverging Side-Walls," Proceedings of International Symposium in Model Testing in Hydraulic Research by CBI \& P at CW E PRS, Pune, September 24-26, 1987.

Mazumder, S.K. (1994). "Stilling Basin with Rapidly Diverging Side Walls for Flumed Hydraulic Structures," Proceedings of National Symposium on Recent Trends in Design of Hydraulic Structures, organized by Department of Civil Engineering, University of Roorkee, Roorkee, March 18-19.

Mazumder, S.K., Ahuja, K.C. (1978). "Optimum length of contracting transition in open channel sub critical flow," Journal of the Institution of Engineers (India). Civil Engineering Division, Vol. 58.

Mazumder, S.K., Deb Roy, I. (1999). "Improved design of a proportional flow meter," ISH Journal of Hydraulic Engineering, Vol. 5, No. 1, pp. 295-312.

Mazumder, S.K. and Gupta, N.K. (1988). "Hydraulic Performance of some conventional type and dagger type groins," J1. Of Civil Engg. Div. Vol. 68, No. CI-4 the Inst of Engrs (I), January 1988.

Mazumder, S.K., Hager, W. (1993).“Supercritical expansion flow in Rouse modified and reversed transitions," Journal of Hydraulic Engineering, ASCE, Vol. 119, No. 2, pp. 201-219.

Mazumder, S.K., Naresh, H.S. (1988). "Use of appurtenances for economic and efficient design of jump type dissipater having diverging side-walls for flumed canal falls," Journal of the Institution of Engineers (India). Civil Engineering Division, Vol. 68, pp. 284-290.

Mazumder, S.K., Rao, J.V. (1971). “Use of short triangular vanes for efficient design of wide-angle open-channel Expansions," Journal of Institution of Engineers (India), Vol. 51, No. 9, pp. 263-268. 
Mazumder, S.K., Sharma, A. (1983). "Stilling Basin with Diverging Side-Walls," Proceedings of XX, IAHR Congress, Vol. 7, Moscow, September 5-7, 1983.

Mazumder, S.K., Sinnigar, R., Essyad, K. (1994). "Control of shock waves in supercritical expansions," Journal of Irrigation \& Power by CBI \& P, Vol. 51, No. 4, pp. 7-16.

Molino, B. (1989). "Effect of Different Shaped Obstacles on a Rapid Stream Expansion," Proceedings of International Conference on Channel Flow and Channel Run-off, Centennial of Mannings Formula, University of Virginia, VA, Department of Civil Engineering, August 22-26, pp. 672-682.

Naresh, H.S. (1980). "Studies on Energy Dissipation Below A Flumed Canal Fall Provided With Stilling Basin Having Expansive (3:1) Transition and Suitable Other Appurtenances," M.Sc. (Engg.) Thesis Submitted to Department of Civil Engineering, Delhi College of Engineering, September 1980, under the supervision of Prof. S.K. Mazumder.

Peterka, A.J. (1958). "Hydraulic Design of Stilling Basins and Energy Dissipaters," US Department of Interior, Bureau of Reclamation, Denver, CO.

Prandtl, L., Tietzens, O.G. (1957). "Applied Hydro and Aerodynamics" (Translated by Rozenhead), Denver Publications, Denver, CO.

Rao, J.V. (1951). "Exit Transitions in Cross-Drainage Works-Basic Studies," Irrigation Research Station, Poondi, Madras, Ann. Research Publication No. 8.

Rouse, H., Bhoota, B.V., Hsu, E.Y. (1951). "Design of Channel Expansions," 4th Paper in High Velocity Flow in Open Channels: A Symposium, Transactions of ASCE, University of Virginia, VA, Vol. 116, Paper no. 2434, pp. 347-363.

Simons Jr, W.P. (n.d.). "Hydraulic Design of Transitions for Small Canals," Engineering Monograph No 33. Published by the US Department of Interior, Bureau of Reclamation.

Smith, C.D., Yu James, N.G. (1966). "Use of baffles in open channel expansion," Journal of the Hydraulics Division, ASCE, Vol. 92, No. 2, pp. 1-17.

USBR (1968). Design of Small Dams," Indian Edition, Oxford \& IBH Publishing Co., Kolkata.

Vischer, D. (1988). “A design Principle to avoid Shock Waves in Chutes," International Symposia on Hydraulics for High Dams, Bejing.

Bradley, J.N. (1970). "Hydraulics of Bridge Waterways," Federal Highway Administration, Hydraulic design Series No. 1.

Hinds, J. (1928). "Hydraulic Design of Flume and Syphon Transitions," Transactions of ASCE, Vol. 92, pp. 1423-1459.

Ippen, A.T., Dawson, J.H. (1951). "Design of Channel Contractions," 3rd Paper in High Velocity Flow in Open Channels: A Symposium, Transactions of ASCE, Vol. 116, pp. 326-346.

Jaeger, C. (1956). "Engineering Fluid Mechanics," Blackie and Sons Ltd., London.

Lagasse, P.F., Schall, F., Johnson, E.V., Richardson, E.V., Chang, F. (1995). "Stream Stability at Highway Structure," Department of Transportation, Federal Highway Administration, Hydraulic Engineering Circular No.20, Washington, DC.

Mazumder, S.K. (1966). "Design of Wide-Angle Open Channel Expansions in SubCritical Flow by Control of Boundary Layer Separation with Triangular Vanes," Ph.D. Thesis submitted to the Indian Institute of Technology, Kharagpur, for the award of Ph.D. degree under the guidance of Prof. J.V. Rao.

Mazumder, S.K. (1971). "Design of Contracting and Expanding Transition in Open Channel Flow," 41st Annual Research session of CBIP, Jaipur, July 1971, Vol. 14, Hydraulic Publication No. 110. 
Mazumder, S.K. (1994). "Stilling Basin with Rapidly Diverging Side Walls for Flumed Hydraulic Structures," Proceedings of National Symposium on Recent Trends in Design of Hydraulic Structures (NASORT DHS-94), organized by Department of Civil Engineering \& Indian Society For Hydraulics, University of Roorkee (now IIT, Roorkee), Roorkee, March 18-19.

Mazumder, S.K. (2016). "Economic and Efficient Method of Design of A Flumed Canal Fall," Presented and Published in Hydro-2015, International Conference on Hydraulics, Water Resources and Coastal Engineering organized by Indian Society for Hydraulics, Pune, December 8-10.

Mazumder, S.K., Hager, W. (1993). "Supercritical expansion flow in Rouse modified and reversed transitions," Journal of Hydraulic Engineering, ASCE, Vol. 119, No. 2, pp. 201-219.

Molesworth, G.L. (1871). "Pocket Book of Engineering Formulae (Useful Formulae and Memoranda) for Civil and Mechanical Engineers," E. \& F.N. Spon, London, 7th Ed. p. 176.

USBR (1968). "Design of Small Dams," Indian Edition, Oxford \& IBH Publishing Co., Kolkata. 